\title{
Evaluation of a complementary based model for mapping land surface evapotranspiration
}

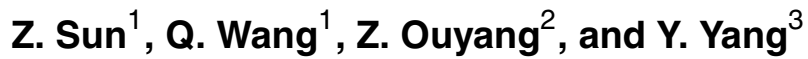

${ }^{1}$ National Institute for Environmental Studies, Tsukuba, Japan

${ }^{2}$ Institute of Geographical Sciences and Natural Resource Research, CAS, Beijing, China

${ }^{3}$ Key Laboratory for Agricultural Water Resources, Center for Agricultural Resources

Research, Institute of Genetics and Developmental Biology, CAS, Shijiazhuang, China

Received: 7 February 2012 - Accepted: 27 February 2012 - Published: 12 March 2012

Correspondence to: Z. Sun (sun.zhigang@ nies.go.jp)

Published by Copernicus Publications on behalf of the European Geosciences Union.

\section{Complementary based model for mapping land surface evapotranspiration}

Z. Sun et al.

\section{Title Page}

Abstract Introduction

Conclusions

References

Tables

Figures

14

4

Back

Full Screen / Esc

Printer-friendly Version

Interactive Discussion 


\section{Abstract}

A modified Priestley-Taylor (P-T) equation was proposed by Venturini et al. (2008) to map actual evapotranspiration (ET) based solely on satellite remote sensing data, involving a parameter based on a scaled temperature between dew point temperature 5 and surface temperature. In this study, however, theoretical analyses and field experimental evidence show that it is hard to obtain this scaled temperature using dew point temperature and surface temperature. This study also presents a new parameterization method using air temperature, surface temperature, and surface temperature of a reference dry surface. The actual ET estimates obtained by means of our proposed parameterization method are validated at a site scale, and a case study is conducted to map actual ET from Advanced Spaceborne Thermal Emission and Reflection radiometer (ASTER) images using our proposed method. Results of ground-based validation and a case study of mapping ET using ASTER images indicate that the improvement on the modified P-T equation proposed by Venturini et al. (2008) can contribute to 15 generating reliable actual ET.

\section{Introduction}

Most methods of mapping land surface evapotranspiration (ET) using satellite remote sensing data depend on auxiliary data from ground measurements or reanalyzed meteorological data. These methods have been derived from the Penman-Monteith equation (e.g. Cleugh et al., 2007; Mu et al., 2007, 2011) or the land surface energy balance equation (e.g. Bastiaanssen et al., 1998; Su, 2002; Mariotto et al., 2011). However, these methods require the aerodynamic resistance and/or stomatal resistance estimates which are hard to obtain on large spatial scales. Hence, ET estimating methods based solely on satellite remote sensing data are highly promising to map ET over
HESSD

9, 3029-3062, 2012

\section{Complementary based model for mapping land surface evapotranspiration}

Z. Sun et al.

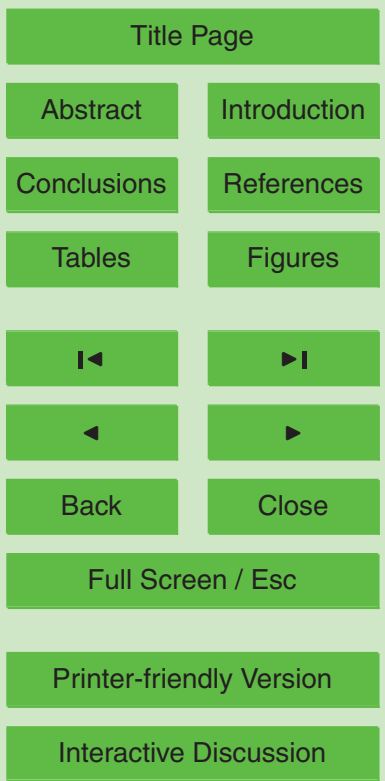


The Priestley-Taylor (P-T) equation (Priestley and Taylor, 1972) has been modified with several versions to map actual ET due to its simple form with few inputs and inputs readily derived from satellite remote sensing images. The P-T equation can be directly used for ET estimation for wet environments while the P-T coefficient $(\alpha)$ is set as a 5 constant of 1.26. For non-wet environments an adjusted value of $\alpha$ or environmental factors constraining ET could be included in the P-T equation for actual ET estimation. A literature review suggests that two methods could be used to determine $\alpha$ for all environments, from the scatter plot of remotely sensed vegetation index ( $\mathrm{VI})$ and surface temperature $\left(T_{\mathrm{s}}\right)$ (Jiang and Islam, 1999, 2001; Wang et al., 2006), and as a 10 function of LAI, soil moisture, and air temperature (Jin et al., 2011). The actual ET for all environments can also be obtained from the P-T equation involving environmental factors constraining ET. Barton (1979) introduced a ratio of surface vapor pressure to surface saturated vapor pressure to the P-T equation for estimating ET from nonsaturated surfaces. Venturini et al. (2008) proposed a dimensionless coefficient $(F)$ to constrain ET. This coefficient is empirically determined using surface temperature and dew point temperature as well as a saturated vapor pressure (SVP) curve. Fisher et al. (2008) estimated actual ET using several constraining indexes including relative surface wetness, plant temperature constraint, plant moisture constraint, and soil moisture constraint.

20 Several studies have reviewed existing modified P-T equations for actual ET estimation (e.g. Kalma et al., 2008; Venturini et al., 2011), while this study focuses on the evaluation of a modified P-T equation proposed by Venturini et al., (2008) (hereafter: the Venturini equation) due to simplifications and assumptions involved in this equation. These simplifications and assumptions may lead to potential errors or uncertainties in

ET estimates, which were not quantificationally evaluated in Venturini et al. (2008) and in the subsequent literature (Kalma et al., 2008; Venturini et al., 2011).

The purpose of this study therefore is to evaluate the simplifications and assumptions involved in the Venturini equation by means of theoretical analyses and field experimental evidence, and to propose a reliable parameterization method to improve the
HESSD

9, 3029-3062, 2012

Complementary

based model for

mapping land surface

evapotranspiration

Z. Sun et al.

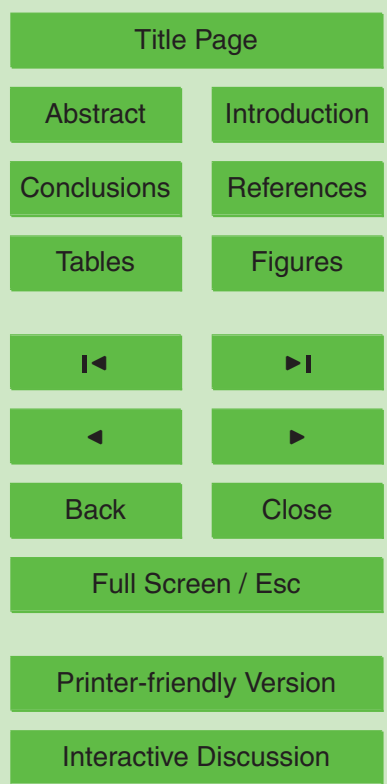




\section{Methodology}

This section firstly describes the Venturini equation and its parameterization (Sect. 2.1), then presents strategies for evaluation on the Venturini equation (Sect. 2.2), further proposes a new parameterization method to improve the Venturini equation (Sect. 2.3), and finally conducts a case study to generate ET maps using Advanced Spaceborne Thermal Emission and Reflection radiometer (ASTER) images along with the improved Venturini equation as well as a well-used modified P-T equation (Jiang and Islam, 1999, 2001; Tang et al., 2010) (Sect. 2.4).

\subsection{Description of the Venturini equation and its parameterization}

The Venturini equation is derived from Granger's complementary relationship (Granger, 1989) and the P-T equation,

$\mathrm{ET}=\mathrm{EF}\left(R_{\mathrm{n}}-G\right)=\alpha\left(\frac{F \Delta}{F \Delta+\gamma}\right)\left(R_{\mathrm{n}}-G\right)$,

where $\mathrm{EF}[-]$ is the evaporation fraction ranging from 0 to $1, \gamma\left[\mathrm{kPa}^{\circ} \mathrm{C}^{-1}\right]$ is the psychro15 metric constant, $\Delta\left[\mathrm{kPa}^{\circ} \mathrm{C}^{-1}\right]$ is the slope of the SVP curve, $\alpha[-]$ is the P-T coefficient given as 1.26, $R_{\mathrm{n}}\left[\mathrm{W} \mathrm{m}^{-2}\right]$ is the net radiation at the land surface, $G\left[\mathrm{~W} / \mathrm{m}^{2}\right]$ is the soil heat flux, and $F$ is a dimensionless coefficient varying from 0 to 1 . When $F=0, E F=0$ and then $\mathrm{ET}=0$; when $F=1$, Eq. (1) is presented as the exact P-T equation, and ET is wet environment evapotranspiration. Similar to EF, therefore, the coefficient of $F$ is also an indicator of land surface moisture condition, and the reliability of ET estimates from Eq. (1) is highly related to the accuracy of $F$ estimates.

\section{Complementary based model for mapping land surface evapotranspiration}

Z. Sun et al.

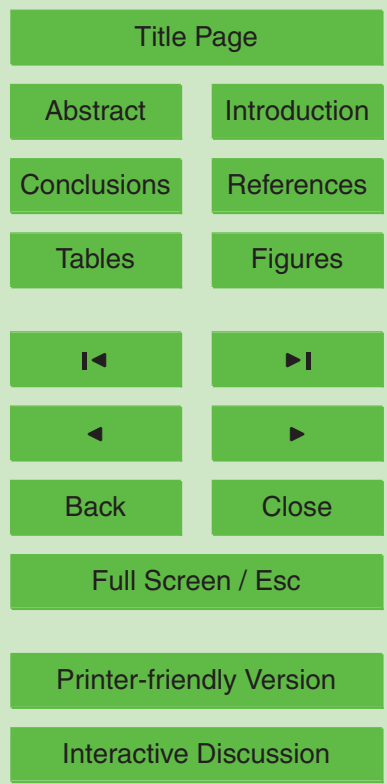




\subsubsection{Parameterization of $F$}

In the Venturini equation, $F$ is defined as a ratio of actual ET to potential ET (ETp),

HESSD

$F=\frac{\mathrm{ET}}{\mathrm{ET}_{\mathrm{p}}}=\frac{f_{\mathrm{u}}\left(e_{\mathrm{s}}-e_{\mathrm{a}}\right)}{f_{\mathrm{u}}\left(e_{\mathrm{s}}^{*}-e_{\mathrm{a}}\right)}=\frac{e_{\mathrm{s}}-e_{\mathrm{a}}}{e_{\mathrm{s}}^{*}-e_{\mathrm{a}}}$,

where $e_{\mathrm{s}}[\mathrm{kPa}]$ is the surface actual vapor pressure, $e_{\mathrm{a}}[\mathrm{kPa}]$ is the air actual vapor 5 pressure, $e_{\mathrm{S}}^{*}[\mathrm{kPa}]$ is the surface saturation vapor pressure, and $f_{\mathrm{u}}$ is a function of the wind speed and the vegetation height. The $f_{\mathrm{u}}$ was suggested to affect ET and $\mathrm{ET}_{\mathrm{p}}$ in a similar manner (Granger, 1989). Venturini et al. (2008) assumed that the SVP curve can be linearized for small temperature differences. It is approximately true for the temperature difference of less than $1^{\circ} \mathrm{C}$, but a further evaluation is required for larger temperature difference. As shown in Fig. 1, if $\Delta_{1}=\frac{e_{\mathrm{s}}-e_{\mathrm{a}}}{T_{\mathrm{u}}-T_{\mathrm{d}}}$ and $\Delta_{2}=\frac{e_{\mathrm{s}}^{*}-e_{\mathrm{a}}}{T_{\mathrm{s}}-T_{\mathrm{d}}}$, Eq. (2) may be changed to,

$F=\frac{T_{\mathrm{u}}-T_{\mathrm{d}}}{T_{\mathrm{s}}-T_{\mathrm{d}}} \frac{\Delta_{1}}{\Delta_{2}}$

where $T_{\mathrm{d}}\left[{ }^{\circ} \mathrm{C}\right]$ is the dew point temperature, $T_{\mathrm{s}}\left[{ }^{\circ} \mathrm{C}\right]$ is the surface temperature, $T_{\mathrm{u}}\left[{ }^{\circ} \mathrm{C}\right]$ is the temperature corresponding to the surface actual vapor pressure on the SVP curve

15 (see Fig . 1). The $\Delta_{1}$ and $\Delta_{2}$ were assumed equal, and $\Delta_{1} / \Delta_{2}$ was removed in the original Eq. (5) presented in Venturini et al. (2008),

$F=\frac{T_{\mathrm{u}}-T_{\mathrm{d}}}{T_{\mathrm{s}}-T_{\mathrm{d}}}$

How would this removal affect the estimates of $F$ and resulting ET? The reasonability of this removal was evaluated in this study.

\subsubsection{Parameterization of $T_{u}$}

Except $T_{\mathrm{u}}$, other variables in Eq. (3) are easy to be obtained from satellite remote sensing or ground measurements. $T_{\mathrm{u}}$ is a virtual parameter, and cannot be directly

Complementary based model for mapping land surface evapotranspiration

Z. Sun et al.

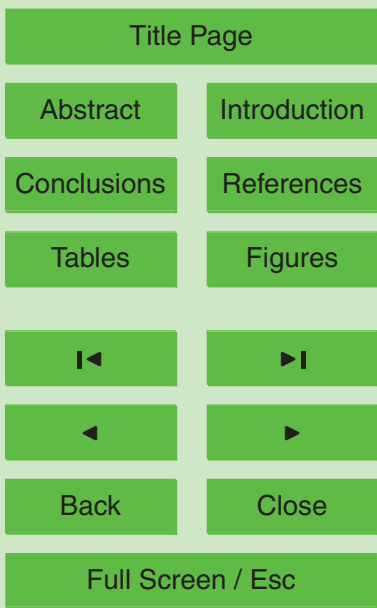

Printer-friendly Version

Interactive Discussion 
measured. Venturini et al. (2008) also used the method of linearizing the SVP curve to derive $T_{\mathrm{u}}$. As shown in Fig. 2, two equations are obtained by linearizing the SVP curve,

$\Delta_{1}^{\prime}=\frac{e_{\mathrm{s}}^{*}-e_{\mathrm{s}}}{T_{\mathrm{s}}-T_{\mathrm{u}}}, \quad \Delta_{1}^{\prime}\left(T_{\mathrm{s}}-T_{\mathrm{u}}\right)=e_{\mathrm{s}}^{*}-e_{\mathrm{s}}$,

$\Delta_{2}^{\prime}=\frac{e_{\mathrm{s}}-e_{\mathrm{a}}}{T_{\mathrm{u}}-T_{\mathrm{d}}}, \quad \Delta_{2}^{\prime}\left(T_{\mathrm{u}}-T_{\mathrm{d}}\right)=e_{\mathrm{s}}-e_{\mathrm{a}}$.

5 Combining Eq. (5a) and Eq. (5b) will yield:

$\Delta_{1}^{\prime}\left(T_{\mathrm{s}}-T_{\mathrm{u}}\right)+\Delta_{2}^{\prime}\left(T_{\mathrm{u}}-T_{\mathrm{d}}\right)=e_{\mathrm{s}}^{*}-e_{\mathrm{a}}$.

Hence:

$T_{\mathrm{u}}=\frac{\left(e_{\mathrm{s}}^{*}-e_{\mathrm{a}}\right)-\Delta_{1}^{\prime} T_{\mathrm{s}}+\Delta_{2}^{\prime} T_{\mathrm{d}}}{\Delta_{2}^{\prime}-\Delta_{1}^{\prime}}$.

Note that $\Delta_{1}^{\prime}$ and $\Delta_{2}^{\prime}$ (Fig. 2) here are different to $\Delta_{1}$ and $\Delta_{2}$ used in Eq. (3) (Fig. 1).

In Eq. (6b), $e_{\mathrm{a}}$ and $e_{\mathrm{s}}^{*}$ can be estimated using $T_{\mathrm{d}}$ and $T_{\mathrm{s}}$ as well as the SVP curve (see Fig. 2). Venturini et al. (2008) used Buck's equation (Buck, 1981) to simulate the SVP curve, and $\Delta_{1}^{\prime}$ and $\Delta_{2}^{\prime}$ were estimated at $T_{\mathrm{s}}$ and $T_{\mathrm{d}}$, respectively. When variables on the right of Eq. (6b) are known, $T_{u}$ can be readily calculated. Trying to reduce the errors resulting from linearizing the SVP curve, Venturini et al. (2008) proposed an iteration 5 process to re-calculate

with the first estimate of $T_{\mathrm{u}}$ and then to compute a new $T_{\mathrm{u}}$. This iterative process is questionable. How many iterations would be required? When would the iterative process stop? How would the estimate of $T_{\mathrm{u}}$ affect the estimates of $F$ and then resulting ET? This method of estimating $T_{\mathrm{u}}$ was evaluated in this study.
HESSD

9, 3029-3062, 2012

\section{Complementary based model for mapping land surface evapotranspiration}

Z. Sun et al.

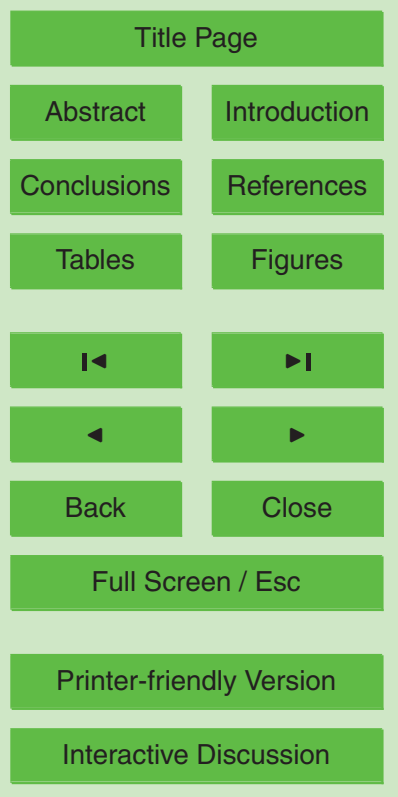




\subsection{Evaluation strategies}

According to assumptions and simplifications described above, three strategies were adopted for evaluation, as shown in Fig. 3.

HESSD

9, 3029-3062, 2012

- Evaluation strategy 1 (ES1):

The value of $F$ is directly obtained from Eq. (2) with the measurements of $T_{\mathrm{s}}$, $e_{\mathrm{s}}$ (vapor pressure at the canopy height), and $e_{\mathrm{a}}$ (at the reference height of $3 \mathrm{~m}$ ) and the resulting ET estimates are compared against ET measurements. This evaluation strategy can reveal the accuracy of Eq. (1) without any uncertainty or error in $F$ and $T_{\mathrm{u}}$ estimates suggested by Venturini et al. (2008).

- Evaluation strategy 2 (ES2 and ES2'):

The value of $F$ is estimated respectively using Eq. (3) (ES2') and Eq. (4) (ES2) along with the measurement of $T_{\mathrm{s}}$ and the estimates of $T_{\mathrm{d}}$ and $T_{\mathrm{u}}$ which is directly derived from $e_{\mathrm{s}}$. This evaluation strategy can show us the reasonability of linearizing the SVP curve and the effect of the removal of $\Delta_{1} / \Delta_{2}$ from Eq. (3) on resulting ET estimates.

- Evaluation strategy 3 (ES3):

The value of $T_{\mathrm{u}}$ is estimated by the iteration method originally proposed by Venturini et al. (2008), and then a series of $F$ values is calculated based on the $T_{\mathrm{u}}$ values resulting from a series of iteration. This strategy can evaluate the iterative process of $T_{\mathrm{u}}$ estimation, and the resulting ET using the method of Venturini et al. (2008).

\subsection{A new parameterization method of $F$}

Surface actual vapor pressure $\left(e_{\mathrm{s}}\right)$ directly indicates the moisture condition of land surface. It is close to surface saturated vapor pressure $\left(e_{\mathrm{s}}^{*}\right)$ when the land surface is

Complementary based model for mapping land surface evapotranspiration

Z. Sun et al.

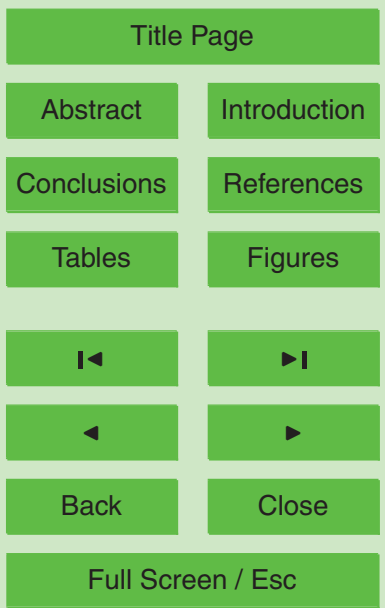

Printer-friendly Version

Interactive Discussion 
wet enough; it is close to air actual vapor pressure $\left(e_{\mathrm{a}}\right)$ when the land surface is dry. Therefore, $e_{\mathrm{s}}$ may be approximated with,

$e_{\mathrm{s}}=\mathrm{WI} e_{\mathrm{s}}^{*}-(1-\mathrm{WI}) e_{\mathrm{a}}$,

where $\mathrm{WI}[-]$ is the wetness index. The WI can be estimated from remote sensing

5 images by means of reference pixels with extreme dry and wet conditions. Following Sandholt et al. (2002) and Sun et al. (2011),

$\mathrm{WI}=\frac{\left(T_{\mathrm{s}}\right)_{\max }-T_{\mathrm{s}}}{\left(T_{\mathrm{s}}\right)_{\max }-T_{\mathrm{a}}}$,

where $T_{\mathrm{a}}\left[{ }^{\circ} \mathrm{C}\right]$ is the air temperature which can be retrieved from wet pixels (e.g. open water surfaces or well-watered closed canopy), and $\left(T_{\mathrm{s}}\right)_{\max }\left[{ }^{\circ} \mathrm{C}\right]$ is the maximum surface

10 temperature which can be retrieved from dry pixels (e.g. dry bare soil, urban areas). A scatter plot of $\mathrm{VI}$ and $T_{\mathrm{s}}$ is also useful to obtain $T_{\mathrm{a}}$ and $\left(T_{\mathrm{s}}\right)_{\max }$ (Sun et al., 2011). Then a new parameterization equation may be obtained as follows,

$F=\frac{e_{\mathrm{s}}-e_{\mathrm{a}}}{e_{\mathrm{s}}^{*}-e_{\mathrm{a}}}=\frac{\mathrm{WI} e_{\mathrm{s}}^{*}-(1-\mathrm{WI}) e_{\alpha}-e_{\mathrm{a}}}{e_{\mathrm{s}}^{*}-e_{\mathrm{a}}}=\mathrm{WI}=\frac{\left(T_{\mathrm{s}}\right)_{\max }-T_{\mathrm{s}}}{\left(T_{\mathrm{s}}\right)_{\max }-T_{\mathrm{a}}}$.

\subsection{A case study to generate ET maps using ASTER images along with the improved Venturini equation as well as a widely-used modified P-T equation}

With the purpose to test the performance of the Venturini equation along with our proposed parameterization method for $F$ to map actual ET, a case study was conducted to generate ET maps using ASTER images. A modified P-T equation proposed by Jiang and Islam (1999) (hereafter: the Jiang equation) and improved by Tang et al. (2010)

\section{HESSD}

9, 3029-3062, 2012

Complementary

based model for

mapping land surface

evapotranspiration

Z. Sun et al.

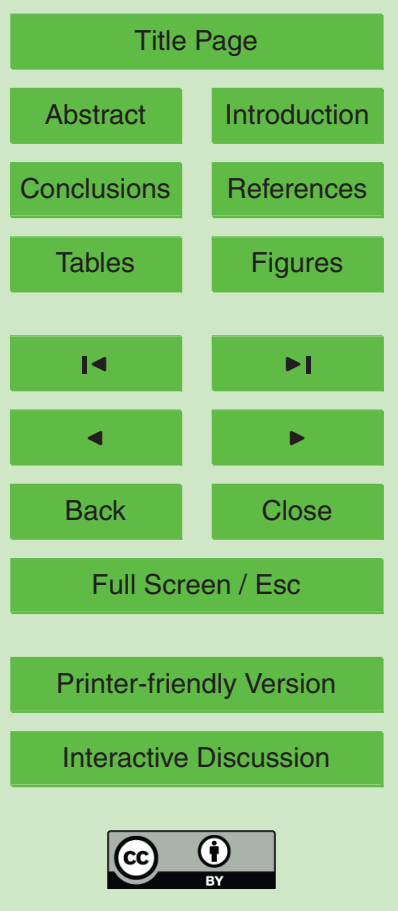


$\gamma$ and $\Delta$ are estimated using $T_{\mathrm{a}}$ and $P$ with equations shown in Fig. 3 . The values of $T_{\mathrm{a}}$ and $\left(T_{\mathrm{s}}\right)_{\max }$ are estimated from $T_{\mathrm{s}}$ values of pixels of open water surface and urban areas in an ASTER image, respectively. The WI and $F$ are then calculated using $T_{\mathrm{a}}$, $T_{\mathrm{s}}$, and $\left(T_{\mathrm{s}}\right)_{\max }$. The estimation of $R_{\mathrm{n}}$ and $G$ as well as related parameters is shown 5 in Table 1 . The values of downward shortwave $\left(R_{\mathrm{sd}}\right)$ and downward long-wave $\left(R_{\mathrm{Id}}\right)$ radiation may be obtained from ground measurements if the size of case study area is not large. Finally, ET is calculated when all inputs available in Eq. (1) are ready.

The flowchart of mapping ET using the Jiang equation is the same as given in Fig. 4 with the exception that the parameterization of $F$ is replaced by the estimation of the 10 adjustable $\mathrm{P}-\mathrm{T}$ coefficient which is determined using a two-step linear interpolation in a $f_{\text {veg }}-T_{\mathrm{s}}$ scatter plot (Jiang and Islam, 1999; Tang et al., 2010).

\section{Study site and data}

\subsection{Study site and observational instruments}

Data for the evaluation were collected from an agroecological station $\left(36^{\circ} 50^{\prime} \mathrm{N}\right.$, $15116^{\circ} 35^{\prime} \mathrm{E}$, and $26 \mathrm{~m}$ a.s.l. - above sea level) located in the North China Plain (NCP) with a semi-arid monsoon climate (Fig. 5). The yearly mean air temperature is $13.1^{\circ} \mathrm{C}$; annual precipitation is $610 \mathrm{~mm}$, of which about $70 \%$ falls between June and August. The land use at the study site and in surrounding areas is mainly irrigated cropland. A rotation cropping system of winter wheat and summer maize dominates in this area. Winter wheat is usually sown in early October and harvested in early June of next year, and the summer maize growing period is between June and October, immediately after the winter wheat harvest.

Since 2002, a flux tower (an eddy covariance system) and an automated meteorological station at the study site record the half-hour measurements of fluxes (heat, vapor, and $\mathrm{CO}_{2}$ ), meteorological factors (air temperature, air humidity, and wind speed) at four heights ( $1 \mathrm{~m}, 3 \mathrm{~m}, 4 \mathrm{~m}$, and $6 \mathrm{~m}$ ) above the ground, air pressure, components of
HESSD

9, 3029-3062, 2012

Complementary

based model for

mapping land surface

evapotranspiration

Z. Sun et al.

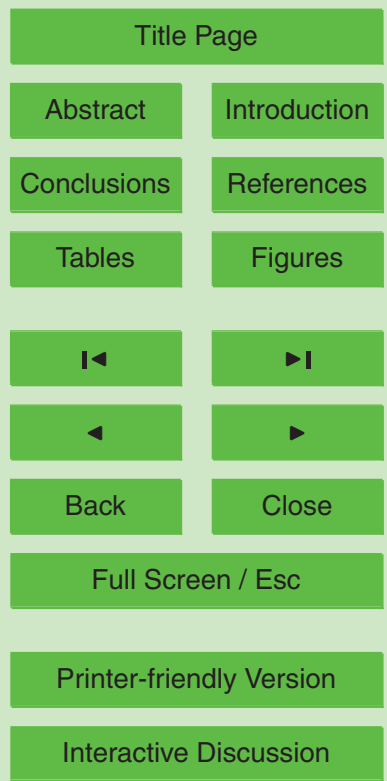


radiation balance (total solar radiation, net radiation, upward and downward shortwave radiation, and upward and downward long wave radiation), surface temperature, soil heat flux, and soil water content. In addition, canopy height and LAI by an LAI2000 plant canopy analyzer (Li-COR Inc., Lincoln, NE, USA) are also measured. Instru5 ments on the flux tower and automated meteorological station were carefully calibrated before installation and are maintained once a year after installation. Details regarding the observation system and measurements were addressed in Watanabe et al. (2005).

With a purpose to evaluate remote sensing ET algorithms with the aid of information of extremely dry pixels (e.g. Bastiaanssen et al., 1998; Sun et al., 2009), another au- tomated meteorological station was installed in a dry bare soil surface location $200 \mathrm{~m}$ north to the flux tower in March 2006. It records half-hour measurements of net radiation, soil heat flux, surface temperature, and soil water content. Details regarding the observation system and measurements were addressed in Sun et al. (2009).

\subsection{Ground data for evaluation on the Venturini equation}

15 With a purpose to ensure that the humidity at the height of $1 \mathrm{~m}$ represents the surface vapor pressure, data required for evaluation (net radiation, soil heat flux, latent heat flux, surface temperature, surface vapor pressure, air temperature, air vapor pressure, and air pressure) were collected on two days when the height of maize canopy was $1 \mathrm{~m}$ (29 July 2003 and 3 August 2010). Figure 6 shows the diurnal patterns of observed 20 surface energy fluxes on 29 July 2003 and 3 August 2010 at the study site, including net radiation $\left(R_{\mathrm{n}}\right)$, latent heat flux $(\mathrm{ET})$, soil heat flux $(G)$, and sensible heat flux $(H)$. During the daytime on two days, the closure rate (i.e. a ratio of the sum of sensible heat flux and latent heat flux to the difference of net radiation and soil heat flux) of eddy covariance measurements ranges from $70 \%$ to $90 \%$ at the study site. As reported in

25 Foken (2008) and Allen et al. (2011), there is no effective technology to fix this "closure error" to date. Following the strategy commonly used in prior studies (e.g. Twine et al., 2000; Jung et al., 2010), the energy balance was'closed'by scaling sensible heat
HESSD

9, 3029-3062, 2012

Complementary based model for mapping land surface evapotranspiration

Z. Sun et al.

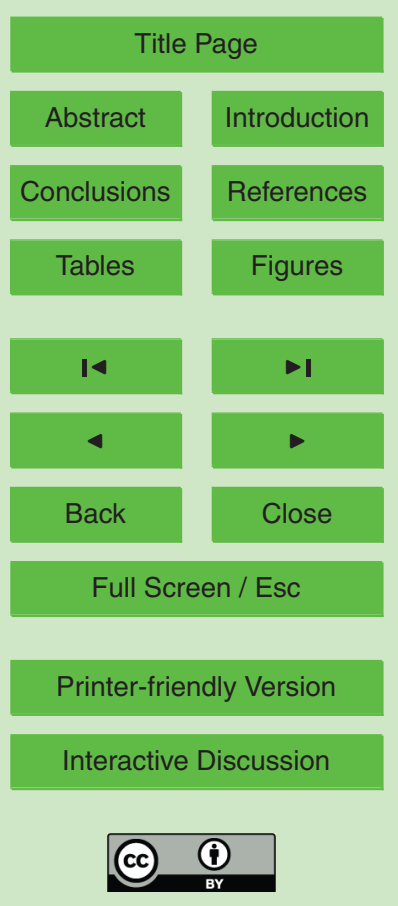


flux and latent heat flux in the same proportion until the sum equals available energy (i.e. $R_{\mathrm{n}}-G$ ) in this study.

\subsection{Ground data for validation of the improvement on the Venturini equation}

Surface temperature data for the dry bare soil surface were collected from the auto5 mated meteorological station during the period of 21 September 2006 to 21 November 2006 when the surface soil water content was close to or less than the wilting coefficient of $10 \%$. Net radiation, soil heat flux, latent heat flux, air temperature, surface temperature, and air pressure were also collected from the flux tower during the same period when land cover around the flux tower was cotton (canopy height was $1.27 \mathrm{~m}$, and leaf area index ranging from 1.52 to 0.42 ).

\subsection{Remote sensing data and ground data for a case study to map actual ET}

Two ASTER level-2 data products (AST07 and AST08) on 9 May 2003 (projection: UTM, 50N; datum: WGS-84) were collected from the Japanese Ground Data System (www.gds.aster.ersdac.or.jp/gds_www2002/index_e.html). AST07 is the atmospheri15 cally corrected surface reflectance, and AST08 is the surface temperature with accuracy of less than $1^{\circ} \mathrm{C}$ (Wang et al., 2009; Barreto et al., 2010). NDVI is calculated using the ASTER red and infrared reflectance, and land surface albedo is calculated from the reflectance of ASTER bands 1, 3, 5, 6, 8, and 9 along with a linear equation suggested by Liang (2001).

20 Air temperature $\left(19.2^{\circ} \mathrm{C}\right)$, air pressure $(101.81 \mathrm{kPa})$, downward shortwave $\left(722 \mathrm{~W} \mathrm{~m}^{-2}\right)$ and downward long-wave $\left(305.5 \mathrm{~W} \mathrm{~m}^{-2}\right)$ radiation, and latent heat flux $\left(194.01 \mathrm{~W} \mathrm{~m}^{-2}\right)$ were collected at the study site at the time of the Terra satellite overpass (11:00 LT - local time) on 9 May 2003. The values of downward shortwave and long wave radiation at the study site could be taken as representative for the entire case 25 study area due to its small size $\left(<80 \mathrm{~km}^{2}\right)$, as shown in Fig. 5 . Air temperature $\left(19.9^{\circ} \mathrm{C}\right)$ derived from reservoir surface pixels (see Fig. 5 for the locations of two reservoirs) is
HESSD

9, 3029-3062, 2012

Complementary based model for mapping land surface evapotranspiration

Z. Sun et al.

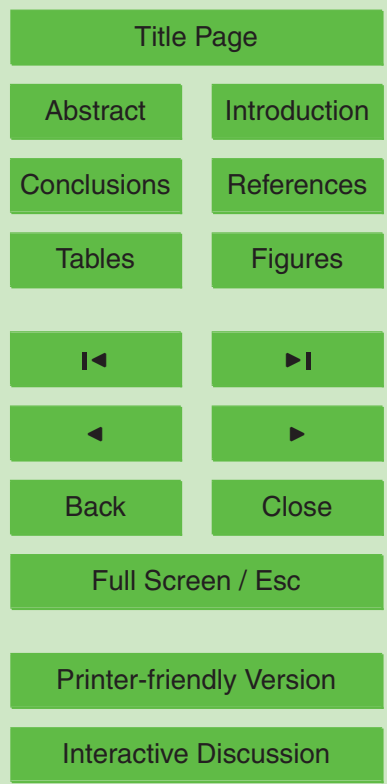


very close its observational value at the study site. The maximum surface temperature is $36.96^{\circ} \mathrm{C}$ derived from hot pixels in Jinan City (Fig. 5).

\section{Results and discussions}

\subsection{Evaluation on the Venturini equation}

5 ET estimates from the four evaluation strategies (ES1, ES2, ES2', and ES3) were compared against ET measurements from the flux tower on 29 July 2003 and 3 August 2010 at the study site. Figure 7 shows the diurnal patterns of ET measurements and ET estimates from four evaluation strategies. The ET estimates from the ES1, ES2, and ES2' agree with the ET measurements, but the 10 ET estimates from the ES3 is obviously larger than the ET measurements, especially near noon. This conclusion can also be obtained from Fig. 8 . The ES1 $\left(y=1.08 \times-7.56, R^{2}=0.88, \mathrm{ME}=-1.37 \mathrm{~W} \mathrm{~m}^{-2}, \mathrm{MAE}=30.89 \mathrm{~W} \mathrm{~m}^{-2}\right)$ and $\mathrm{ES} 2^{\prime}$ $\left(y=1.08 \times-7.61, R^{2}=0.88, \mathrm{ME}=-1.09 \mathrm{~W} \mathrm{~m}^{-2}, \mathrm{MAE}=30.93 \mathrm{~W} \mathrm{~m}^{-2}\right)$ can estimate ET with a very similar accuracy, where $x$ and $y$ are the variables for a linear regression 15 analysis, $R$ is the correlation coefficient, ME is the mean bias, and MAE is the mean absolute bias. The ES2 has a similar accuracy to the ES1 and ES2'; the ME increases to $5.20 \mathrm{~W} \mathrm{~m}^{-2}$, and the MAE increases to $32.67 \mathrm{~W} \mathrm{~m}^{-2}$. However, the ES3 estimates ET with a relatively poor accuracy; the ME increases to $42.82 \mathrm{~W} \mathrm{~m}^{-2}$, and the MAE increases to $60.11 \mathrm{~W} \mathrm{~m}^{-2}$.

\subsubsection{The reasonability of Eq. (1)}

If uncertainties or errors in $F$ and $T_{\mathrm{u}}$ estimates are excluded, and if all inputs are from ground measurements, results from Figs. 7 and 8 (ES1) suggest that the method proposed by Venturini et al. (2008) can accurately estimate ET $\left(M E=-1.37 \mathrm{~W} \mathrm{~m}^{-2}\right.$, $\mathrm{MAE}=30.89 \mathrm{~W} \mathrm{~m}^{-2}$ ). In this study, $e_{\mathrm{s}}^{*}$ was calculated using $T_{\mathrm{s}}$ as well as the SVP
HESSD

9, 3029-3062, 2012

Complementary

based model for

mapping land surface

evapotranspiration

Z. Sun et al.

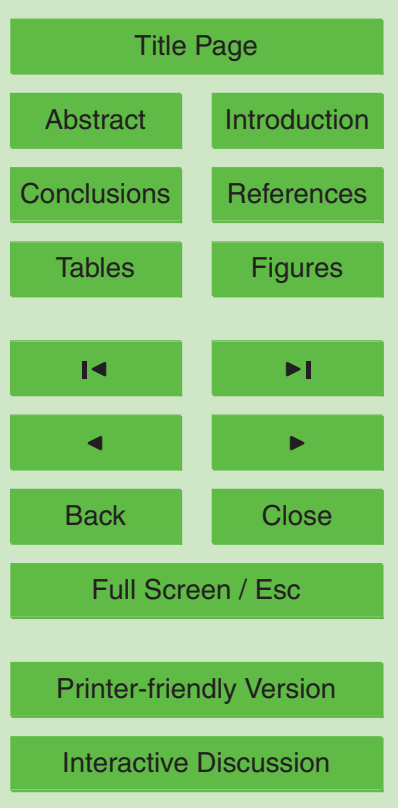

Interactive Discussion 
curve, $e_{\mathrm{a}}$ was calculated using air temperature and air relative humidity, and $e_{\mathrm{s}}$ was calculated using $e_{\mathrm{s}}^{*}$ and relative humidity measured in the vegetation canopy. Figure 9 shows the diurnal patterns of surface actual vapor pressure, air actual vapor pressure, and surface saturated vapor pressure on 9 July 2003 and 3 August 2010 at the study 5 site. Our results indicate that the basic equation (Eq. 1 in this study) proposed by Venturini et al. (2008) is acceptable.

\subsubsection{The reasonability of linearizing the SVP curve}

The comparison of ES2' against ES1 in Figs. 7 and 8 suggests that the approach of linearizing the SVP curve proposed by Venturini et al. (2008) is acceptable. The difference in ME between ES1 and ES2 ${ }^{\prime}$ is only $0.28 \mathrm{~W} \mathrm{~m}^{-2}$, and the difference in MAE is only $0.04 \mathrm{~W} \mathrm{~m}^{-2}$.

\subsubsection{The effect of the removal of $\Delta_{1} / \Delta_{2}$ from Eq. (3) on resulting ET estimates}

The ES2 estimates ET without the item of $\Delta_{1} / \Delta_{2}$ which is involved in ES2' where $\Delta_{1}$ and $\Delta_{2}$ are estimated at the average of $T_{\mathrm{d}}$ and $T_{\mathrm{u}}$ and at the average of $T_{\mathrm{d}}$ and $T_{\mathrm{s}}$, 15 respectively. The comparison between the ES2 and ES2' shows that the removal of $\Delta_{1} / \Delta_{2}$ could cause few errors (the ME increases from $-1.09 \mathrm{~W} \mathrm{~m}^{-2}$ to $5.20 \mathrm{~W} \mathrm{~m}^{-2}$, and the MAE increases from $30.93 \mathrm{~W} \mathrm{~m}^{-2}$ to $32.67 \mathrm{~W} \mathrm{~m}^{-2}$ in this study). This suggests that the removal of $\Delta_{1} / \Delta_{2}$ is a reasonable simplification.

\subsubsection{The reasonability of $T_{\mathrm{u}}$ estimates by linearizing the SVP curve}

20 The comparison of ES3 against other evaluation strategies shows that the ES3 is not capable of estimating ET with an acceptable accuracy. Its ME and MAE have increased to $42.82 \mathrm{~W} \mathrm{~m}^{-2}$ and $60.11 \mathrm{~W} \mathrm{~m}^{-2}$, respectively, in this study. This is inherently caused by the $T_{\mathrm{u}}$ estimation method proposed by Venturini et al. (2008). Figure 10 shows that $T_{\mathrm{u}}$ estimates using Eq. (6) and $T_{\mathrm{u}}$ estimates using Eq. (6) with one iteration are
HESSD

9, 3029-3062, 2012

Complementary based model for mapping land surface evapotranspiration

Z. Sun et al.

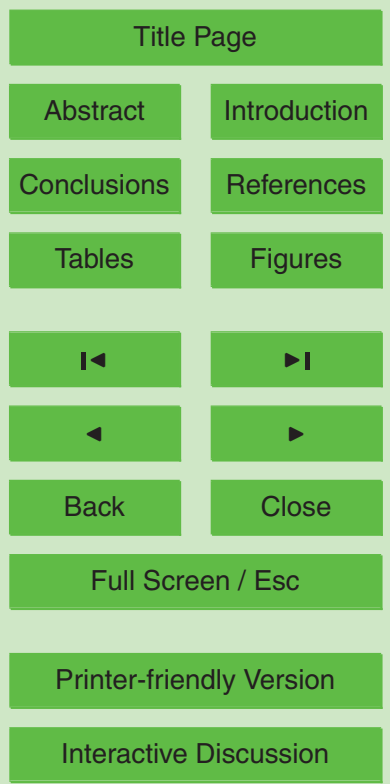


obviously larger than $T_{\mathrm{u}}$ values directly calculated using surface vapor pressure. Furthermore, a test with an increasing number of iterations was conducted in this study. The values of $T_{\mathrm{d}}, T_{\mathrm{a}}$, and $T_{\mathrm{s}}$ have been taken as assumed as $20^{\circ} \mathrm{C}, 22^{\circ} \mathrm{C}$, and $30{ }^{\circ} \mathrm{C}$, respectively. As shown in Fig. 11, $T_{\mathrm{u}}$ and resulting values of $\Delta_{2}, F$, and EF increase 5 with the number of iterations, up to their thresholds. When the number of iterations is more than 50 , the $T_{\mathrm{u}}$ estimate is very close to the given value of $T_{\mathrm{s}}$, the $\Delta_{2}^{\prime}$ estimate is very close to $1.9 \mathrm{hPa}^{\circ} \mathrm{C}^{-1}$, the $F$ estimate is very close to 1 , and the EF estimate is very close to 0.9 . Theoretically, $T_{\mathrm{u}}$ could be any value between $T_{\mathrm{d}}$ and $T_{\mathrm{s}}$. As shown in Fig. 2, Eq. (6b) could always be derived regardless of the value of $T_{\mathrm{u}}$ as long as $T_{\mathrm{u}}$ lies 10 between $T_{\mathrm{d}}$ and $T_{\mathrm{s}}$.

\subsection{Validation of the improved Venturini equation (Eqs. 1 and 9)}

Figure 12 compares ET measurements from the flux tower against ET estimates from the improved Venturini equation (Eqs. 1 and 9) during the period of 21 September 2006 to 21 November 2006 at the study site. They have a high correlation $\left(R^{2}=0.91\right)$, but 15 ET tends to be slightly overestimated $\left(\mathrm{ME}=24.57 \mathrm{~W} \mathrm{~m}^{-2}, \mathrm{MAE}=32.87 \mathrm{~W} \mathrm{~m}^{-2}\right)$. Results from Fig. 12 show that Eq. (9) proposed in this study could improve the Venturini equation and help to accurately estimate ET.

\subsection{Results of case study for mapping ET using ASTER data}

Figure 13 shows ASTER-based ET maps using the improved Venturini equation and the Jiang equation, respectively. The ET estimates $\left(238.25 \mathrm{~W} \mathrm{~m}^{-2}\right.$ and $\left.183.41 \mathrm{~W} \mathrm{~m}^{-2}\right)$ of the ASTER pixel corresponding to the study site on the two ET maps are close to the ground ET measurement $\left(194.01 \mathrm{~W} \mathrm{~m}^{-2}\right)$. The Jiang equation could generate remote sensing-based ET estimates with a root mean square error ranging from $36.47 \mathrm{~W} \mathrm{~m}^{-2}$ to $85.3 \mathrm{~W} \mathrm{~m}^{-2}$ in the Southern Great Plains (Jiang and Islam, 1999, 2001). Furtherwater surfaces mainly range from $200 \mathrm{~W} \mathrm{~m}^{-2}$ to $400 \mathrm{~W} \mathrm{~m}^{-2}$, and ET estimates for most

HESSD

9, 3029-3062, 2012

Complementary

based model for

mapping land surface

evapotranspiration

Z. Sun et al.

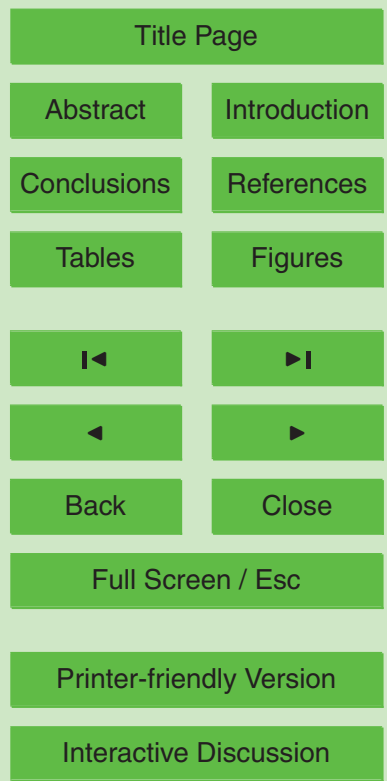


urban and suburban areas are less than $200 \mathrm{Wm}^{-2}$. Figure 14 is the difference map (ET map based on the improved Venturini equation minus ET map based on the Jiang equation). There are small differences $\left(-20 \mathrm{~W} \mathrm{~m}^{-2} \sim 40 \mathrm{~W} \mathrm{~m}^{-2}\right)$ in cropland areas and open water surfaces, but relatively large differences $\left(40 \mathrm{~W} \mathrm{~m}^{-2} \sim 80 \mathrm{~W} \mathrm{~m}^{-2}\right)$ in urban

5 and suburban areas. This case study suggests that the improved Venturini equation could be useful for mapping ET with acceptable accuracies.

\section{Conclusions}

A modified P-T equation was proposed by Venturini et al. (2008) to map actual ET exclusively from satellite remote sensing data, in which a parameter based on a scaled temperature between dew point temperature and surface temperature is involved to transfer potential ET to actual ET. However, the present study has shown that the current parameterization method of $T_{\mathrm{u}}$ is questionable, and that resulting ET estimates are unreliable. If $T_{\mathrm{u}}$ is estimated directly from surface vapor pressure, the Venturini equation is still applicable for actual ET estimation. There is no effective method available to retrieve surface vapor pressure directly from satellite remote sensing to date. This will limit its application with remote sensing. However, microwave remote sensing can provide the moisture information for soil (e.g. Hong and Shin, 2011; Jonard et al., 2011), and canopy moisture is related to soil moisture (e.g. Egea et al., 2011). Therefore, microwave remote sensing may provide a promising tool for $T_{\mathrm{u}}$ retrieval.

Alternatively, this study has proposed a new parameterization method of $F$ by means of a wetness index which is determined using air temperature, surface temperature, and surface temperature of reference dry surface. All these temperature parameters are readily retrieved from thermal satellite images. Results of ground-based validation and a case study of mapping ET using ASTER images indicate that this improvement
HESSD

9, 3029-3062, 2012

\section{Complementary based model for mapping land surface evapotranspiration}

Z. Sun et al.

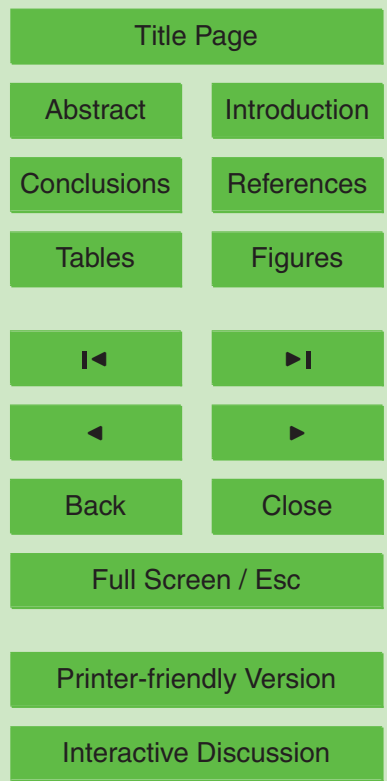


Acknowledgements. This study is supported by the project of "Establishment of Early Detection Network of the Global Warming Impacts", sponsored by the Ministry of the Environment, Japan, and by the sub-project of "Development of Land Surface Evapotranspiration Algorithm based on GCOM-C1", the GCOM (Global Change Observation Mission) project, sponsored by the 5 Japan Aerospace Exploration Agency (JAXA).

\section{References}

Allen, R. G., Pereira, L. S., Howell, T. A., and Jensen, M. E.: Evapotranspiration information reporting: I. Factors governing measurement accuracy, Agr. Water Manage., 98, 899-920, 2011.

Barreto, A., Arbelo, M., Hernandez-Leal, P. A., Nunez-Casillas, L., Mira, M., and Coll, C.: Evaluation of surface temperature and emissivity derived from ASTER Data: a case study using ground-based measurements at a volcanic site, J. Atmos. Ocean. Tech., 27, 1677-1688, 2010.

Barton, I. J.: A parameterization of the evaporation from nonsaturated surfaces, J. Appl. Meteorol., 18, 43-47, 1979.

Bastiaanssen, W. G. M., Menenti, M., Feddes, R. A., and Holtslag, A. A. M.: A remote sensing surface energy balance algorithm for land (SEBAL) 1. Formulation, J. Hydrol., 212-213, 198-212, 1998.

Buck, A. L.: New equations for computing vapor pressure and enhancement factor, J. Appl. Meteorol., 20, 1527-1532, 1981.

Cleugh, H. A., Leuning, R., Mu, Q., and Running, S. W.: Regional evaporation estimates from flux tower and MODIS satellite data, Remote Sens. Environ., 106, 285-304, 2007.

Egea, G., Verhoef, A., and Vidale, P. L.: Towards an improved and more flexible representation of water stress in coupled photosynthesis-stomatal conductance models, Agr. Forest Meteorol., 151, 1370-1384, 2011.

Fisher, J. B., Tu, K. P., and Baldocchi, D. D.: Global estimates of the land-atmosphere water flux based on monthly AVHRR and ISLSCP-II data, validated at 16 FLUXNET sites, Remote Sens. Environ., 112, 901-919, 2008.

Foken, T.: The energy balance closure problem: an overview, Ecol. Appl., 18, 1351-1367, 2008.
HESSD

9, 3029-3062, 2012

\section{Complementary based model for mapping land surface evapotranspiration}

Z. Sun et al.

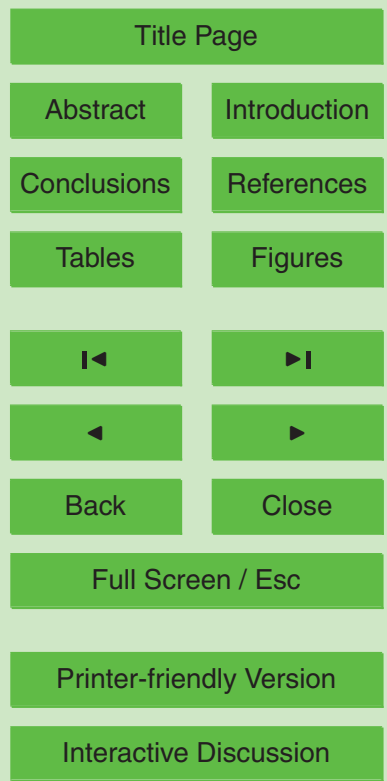


Granger, R. J.: A complementary relationship approach for evaporation from nonsaturated surfaces, J. Hydrol., 111, 31-38, 1989.

Hong, S. and Shin, I.: A physically-based inversion algorithm for retrieving soil moisture in passive microwave remote sensing, J. Hydrol., 405, 24-30, 2011.

5 Jiang, L. and Islam, S.: A methodology for estimation of surface evapotranspiration over large areas using remote sensing observations, Geophys. Res. Lett., 26, 2773-2776, 1999.

Jiang, L. and Islam, S.: Estimation of surface evaporation map over southern Great Plains using remote sensing data, Water Resour. Res., 37, 329-340, 2001.

Jin, Y. F., Randerson, J. T., and Goulden, M. L.: Continental-scale net radiation and evapotranspiration estimated using MODIS satellite observations, Remote Sens. Environ., 115, 2302-2319, 2011.

Jonard, F., Weihermuller, L., Jadoon, K. Z., Schwank, M., Vereecken, H., and Lambot, S.: Mapping field-scale soil moisture with I-band radiometer and ground-penetrating radar over bare soil, IEEE T. Geosci. Remote, 49, 2863-2875, 2011.

15 Jung, M., Reichstein, P., Ciais, S., Seneviratne, I., Sheffield, J., Goulden, M. L., Bonan, G., Cescatti, A., Chen, J., de Jeu, R., Dolman, A. J., Eugster, W., Gerten, D., Gianelle, D., Gobron, N., Heinke, J., Kimball, J., Law, B. E., Montagnani, L., Mu, Q., Mueller, B., Oleson, K., Papale, D., Richardson, A. D., Roupsard, O., Running, S., Tomelleri, E., Viovy, N., Weber, U., Williams, C., Wood, E., Zaehle, S., and Zhang, K.: Recent decline in the global land evapotranspiration trend due to limited moisture supply, Nature, 467, 951-954, doi:10.1038/nature09396, 2010.

Kalma, J. D., McVicar, T. R., and McCabe, M. F.: Estimating land surface evaporation: a review of methods using remotely sensed surface temperature data, Surv. Geophys., 29, 421-469, 2008.

Liang, S. L.: Narrowband to broadband conversions of land surface albedo I Algorithms, Remote Sens. Environ., 76, 213-238, 2001.

Mariotto, I., Gutschick, V. P., and Clason, D. L.: Mapping evapotranspiration from aster data through gis spatial integration of vegetation and terrain features, Photogramm. Eng. Remote Sens., 77, 483-493, 2011.

so Mu, Q., Heinsch, F. A., Zhao, M., and Running, S. W.: Development of a global evapotranspiration algorithm based on MODIS and global meteorology data, Remote Sens. Environ., 111, 519-536, 2007.

\section{HESSD}

9, 3029-3062, 2012

\section{Complementary based model for mapping land surface evapotranspiration}

Z. Sun et al.

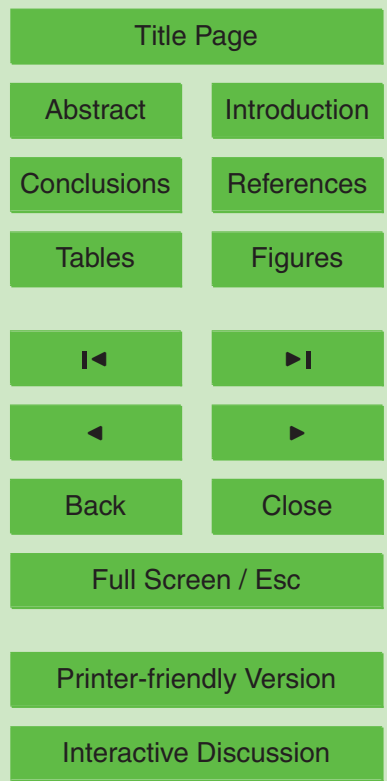


Mu, Q., Zhao, M., and Running, S. W.: Improvements to a MODIS global terrestrial evapotranspiration algorithm, Remote Sens. Environ., 115, 1781-1800, 2011.

Priestley, C. H. B. and Taylor, R. J.: On the assessment of surface heat flux and evaporation using large-scale parameters, Mon. Weather Rev., 100, 81-92, 1972.

5 Sandholt, I., Rasmussen, K., and Andersen, J.: A simple interpretation of the surface temperature/vegetation index space for assessment of surface moisture status, Remote Sens. Environ., 79, 213-224, 2002.

Su, Z.: The Surface Energy Balance System (SEBS) for estimation of turbulent heat fluxes, Hydrol. Earth Syst. Sci., 6, 85-100, doi:10.5194/hess-6-85-2002, 2002.

10 Sun, Z., Wang, Q., Matsushita, B., Fukushima, T., Ouyang, Z., and Watanabe, M.: Development of a Simple Remote Sensing EvapoTranspiration model (Sim-ReSET): Algorithm and model test, J. Hydrol., 376, 476-485, 2009.

Sun, Z., Wang, Q., Matsushita, B., Fukushima, T., Ouyang, Z., Watanabe, M., and Gebremichael, M.: Evaluation of the VI-Ts method for estimating the land surface moisture index and air temperature using ASTER and MODIS data in the North China Plain, Int. J. Remote Sens., 32, 7257-7278, doi:10.1080/01431161.2010.519743, 2011.

Tang, R., Li, Z., and Tang, B.: An application of the $T_{\mathrm{s}}-\mathrm{VI}$ triangle method with enhanced edges determination for evapotranspiration estimation from MODIS data in arid and semiarid regions: Implementation and validation, Remote Sens. Environ., 114, 540-551, 2010.

20 Twine, T. E., Kustas, W. P., Norman, J. M., Cook, D. R., Houser, P. R., Meyers, T. P., Prueger, J. H., Starks, P. J., and Wesely, M. L.: Correcting eddy-covariance flux underestimates over a grassland, Agr. Forest Meteorol., 103, 279-300, 2010.

Venturini, V., Islam, S., and Rodriguez, L.: Estimation of evaporative fraction and evapotranspiration from MODIS products using a complementary based model, Remote Sens. Environ., 112, 132-141, 2008.

Venturini, V., Rodriguez, L., and Bisht, G.: A comparison among different modified Priestley and Taylor equations to calculate actual evapotranspiration with MODIS data, Int. J. Remote Sens., 32, 1319-1338, 2011.

Wang, K., Li, Z., and Cribb, M.: Estimation of evaporative fraction from a combination of day and night land surface temperature and NDVI: A new method to determine the Priestley-Taylor parameter, Remote Sens. Environ., 102, 293-305, 2006.

HESSD

9, 3029-3062, 2012

\section{Complementary based model for mapping land surface evapotranspiration}

Z. Sun et al.

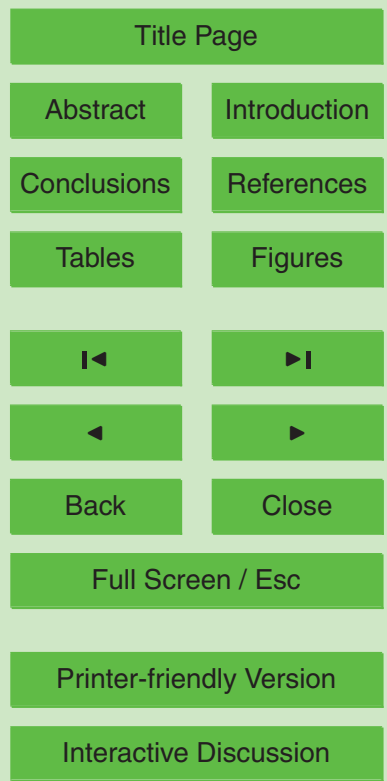


Wang, K. C. and Liang, S. L.: Evaluation of ASTER and MODIS land surface temperature and emissivity products using long-term surface long wave radiation observations at SURFRAD sites, Remote Sens. Environ., 113, 1556-1565, 2009.

Watanabe, M., Wang, Q. X., and Hayashi, S.: Monitoring and simulation of water, heat, and $5 \mathrm{CO}_{2}$ fluxes in terrestrial ecosystems based on the APEIS-FLUX system, J. Geogr. Sci., 15, 131-141, 2005.

\section{HESSD}

9, 3029-3062, 2012

\section{Complementary based model for mapping land surface evapotranspiration}

Z. Sun et al.

Title Page

Abstract

Conclusions

Tables

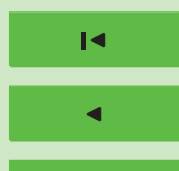

Back
Introduction

References

Figures

$\rightarrow 1$

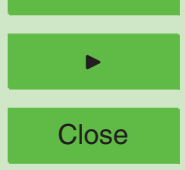

Full Screen / Esc

Printer-friendly Version 


\section{HESSD}

9, 3029-3062, 2012

Table 1. Parameters and their estimation equations for mapping ET using the improved Venturini equation and the Jiang equation.

\begin{tabular}{|c|c|c|c|}
\hline Parameter & Equation & Note & Reference \\
\hline $\begin{array}{l}\text { Vegetation } \\
\text { cover } \\
\text { fraction, } f_{\text {veg }}\end{array}$ & $f_{\text {veg }}=\left(\frac{\mathrm{NDVI}-\mathrm{NDVI}_{\min }}{\mathrm{NDVI}_{\max }-\mathrm{NDVI}_{\min }}\right)^{2}$ & $\begin{array}{l}\mathrm{NDVI}_{\text {min }} \text { and } \mathrm{NDVI}_{\text {max }} \text { are set as } \\
0.125 \text { and } 0.675 \text { for ASTER } \\
\text { images in this study. }\end{array}$ & $\begin{array}{l}\text { Tang et al. (2010); } \\
\text { Sun et al. (2011) }\end{array}$ \\
\hline Emissivity, $\varepsilon$ & $\begin{array}{l}\varepsilon=f_{\text {veg }} \varepsilon_{\text {veg }}+\left(1-f_{\text {veg }}\right) \varepsilon_{\text {soil }} \\
\varepsilon_{\text {soil }}=W I \varepsilon_{\text {soil-wet }}+(1-W I) \varepsilon_{\text {soil-dry }}\end{array}$ & $\begin{array}{l}\varepsilon_{\text {veg }} \text { and } \varepsilon_{\text {soil-wet }} \text { are set as } \\
0.98 \text {, and } \varepsilon_{\text {soil-dry }} \text { is set as } 0.89 \text {. }\end{array}$ & Sun et al. (2009) \\
\hline $\begin{array}{l}\text { Ratio of } G \text { to } \\
R_{\mathrm{n}}, \Gamma\end{array}$ & $\begin{array}{l}\Gamma=f_{\text {veg }} \Gamma_{\text {veg }}+\left(1-f_{\text {veg }}\right) \Gamma_{\text {soil }} \\
\Gamma_{\text {soil }}=\mathrm{WI} \Gamma_{\text {soil-wet }}+(1-\mathrm{WI}) \Gamma_{\text {soil-dry }}\end{array}$ & $\begin{array}{l}\Gamma_{\text {veg }} \text { and } \Gamma_{\text {soil-wet }} \text { are set as } 0.1 \text {, } \\
\text { and } \Gamma_{\text {soil-dry }} \text { is set as } 0.4 .\end{array}$ & Sun et al. (2009) \\
\hline $\begin{array}{l}\text { Net radiation, } \\
R_{\mathrm{n}}\end{array}$ & $R_{\mathrm{n}}=(1-$ albedo $) R_{\mathrm{sd}}+R_{\mathrm{ld}}-\varepsilon \sigma\left(T_{\mathrm{s}}+273.15\right)^{4}$ & $\begin{array}{l}R_{\mathrm{sd}} \text { and } R_{\mathrm{Id}} \text { are from ground } \\
\text { measurements. }\end{array}$ & - \\
\hline $\begin{array}{l}\text { Soil heat flux, } \\
G\end{array}$ & $G=\Gamma R_{\mathrm{n}}$ & - & - \\
\hline
\end{tabular}

Complementary based model for mapping land surface evapotranspiration

Z. Sun et al.

Title Page

Abstract

Introduction

Conclusions

References

Tables

Figures

14

$>$ I

4

Back

Close

Full Screen / Esc

Printer-friendly Version

Interactive Discussion 


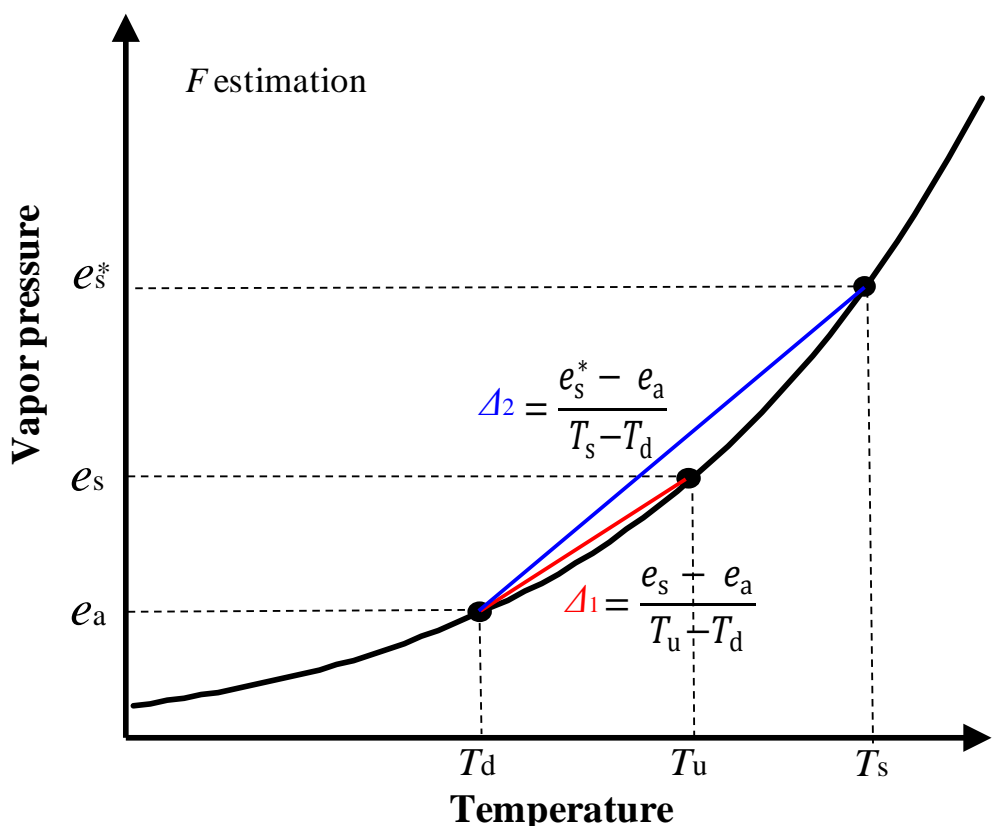

Fig. 1. Parameterization of $F$ by means of the SVP curve (after Venturini et al., 2008).

\section{HESSD}

9, 3029-3062, 2012

\section{Complementary based model for} mapping land surface evapotranspiration

Z. Sun et al.

Title Page

Abstract

Introduction

Conclusions

References

Tables

Figures

14

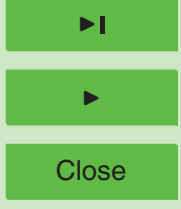

Back

Full Screen / Esc

Printer-friendly Version

Interactive Discussion 


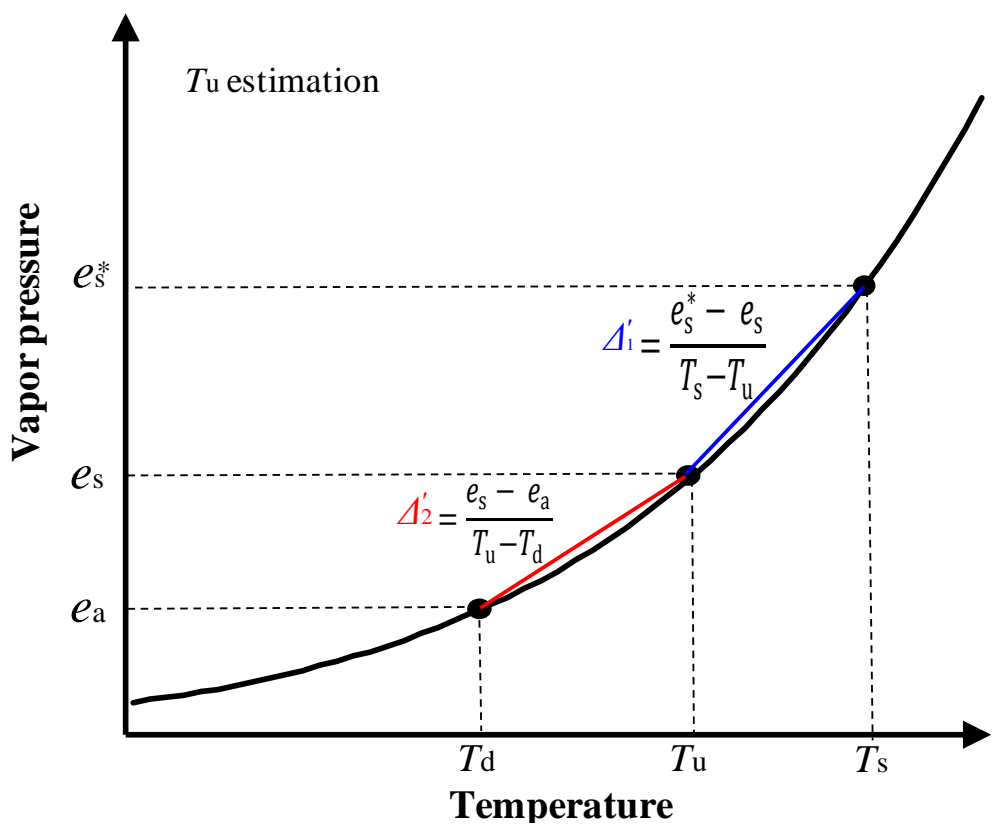

Fig. 2. Parameterization of $T_{\mathrm{u}}$ by means of the SVP curve (after Venturini et al., 2008).

\section{HESSD}

9, 3029-3062, 2012

\section{Complementary based model for} mapping land surface evapotranspiration

Z. Sun et al.

Title Page

Abstract

Introduction

Conclusions

References

Tables

Figures

14

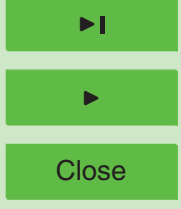

Back

Full Screen / Esc

Printer-friendly Version

Interactive Discussion 


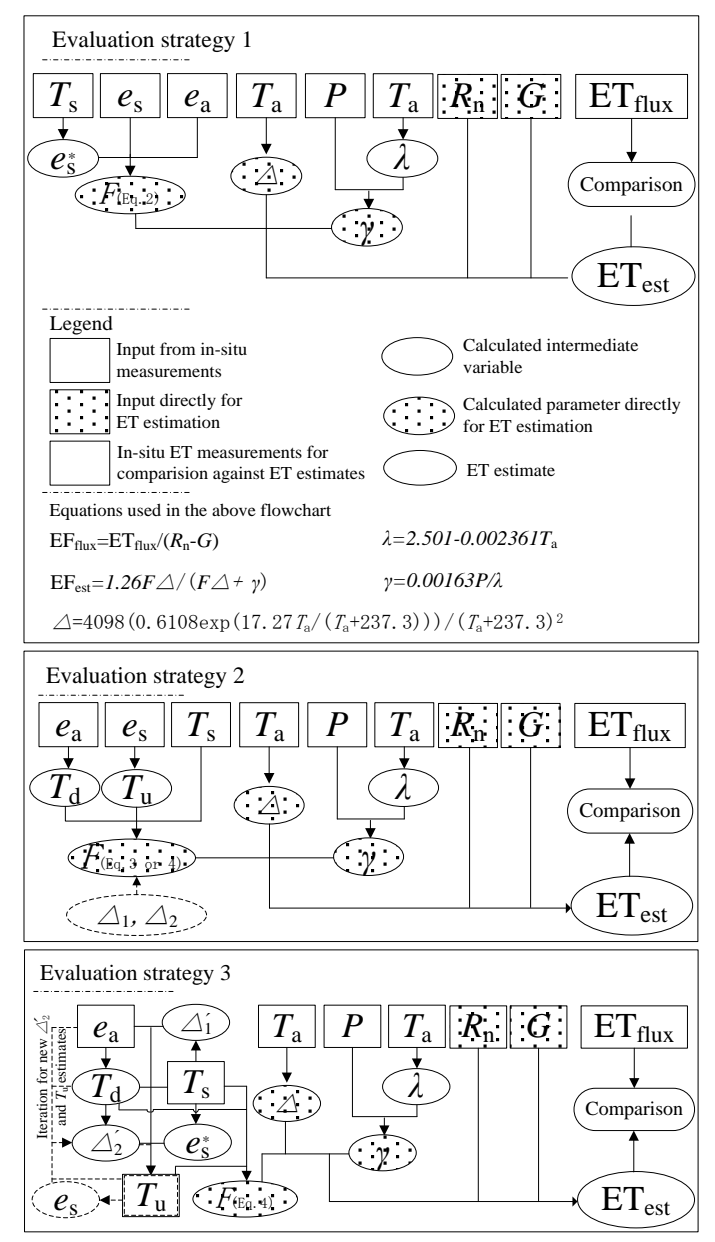

\section{HESSD}

9, 3029-3062, 2012

\section{Complementary based model for mapping land surface evapotranspiration}

Z. Sun et al.

Title Page

Abstract Introduction

Conclusions

References

Tables

Figures

14

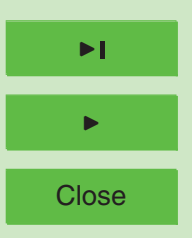

Back

Close

Full Screen / Esc

Printer-friendly Version

Fig. 3. Evaluation strategies adopted in this study. $P[\mathrm{kPa}]$ is the atmospheric pressure, $T_{\mathrm{a}}\left[{ }^{\circ} \mathrm{C}\right]$ is the air temperature, and $\lambda\left[\mathrm{MJ} \mathrm{kg}^{-1}\right]$ is the latent heat of vaporization. 
HESSD

9, 3029-3062, 2012

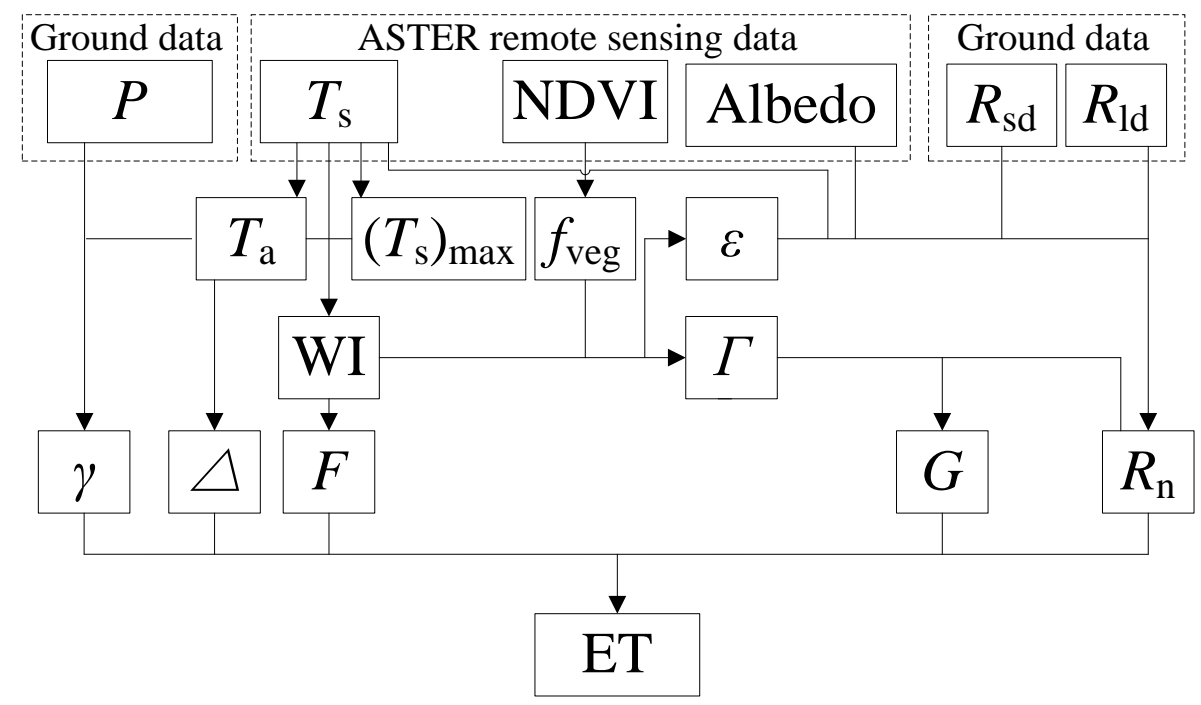

\section{Complementary based model for mapping land surface evapotranspiration}

Z. Sun et al.

Fig. 4. The flowchart of the case study to map ET using ASTER data along with the improved Venturini equation (Eqs. 1 and 9).

Title Page

Abstract

Introduction

Conclusions

References

Tables

Figures

14

4

Back

Close

Full Screen / Esc

Printer-friendly Version

Interactive Discussion 


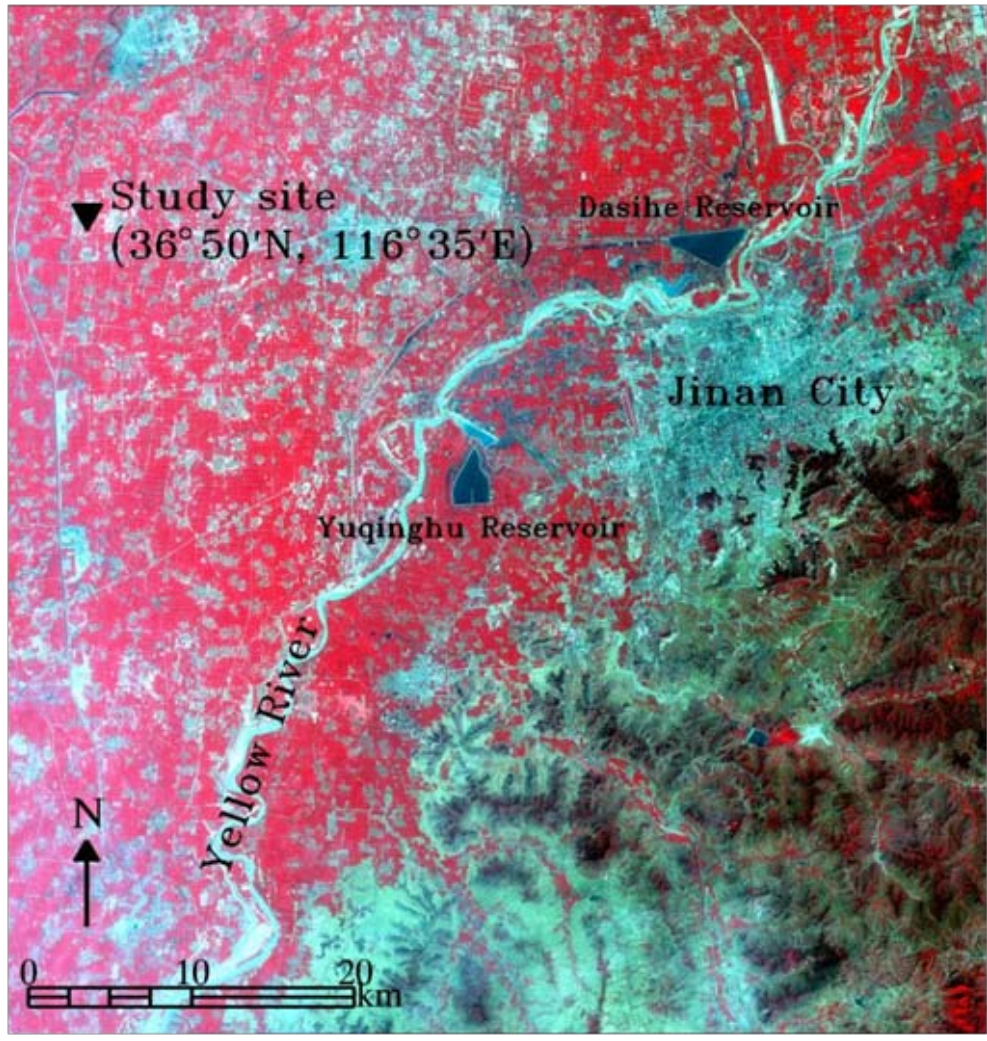

Fig. 5. The study site and the study area for a case study of mapping ET. The remote sensing image is a composite of bands 3,2 and 1 of ASTER (spatial resolution: $15 \mathrm{~m}$; satellite platform: EOS-Terra; observation date: 9 May 2003). The red areas are cropland.

\section{HESSD}

9, 3029-3062, 2012

\section{Complementary based model for mapping land surface evapotranspiration}

Z. Sun et al.

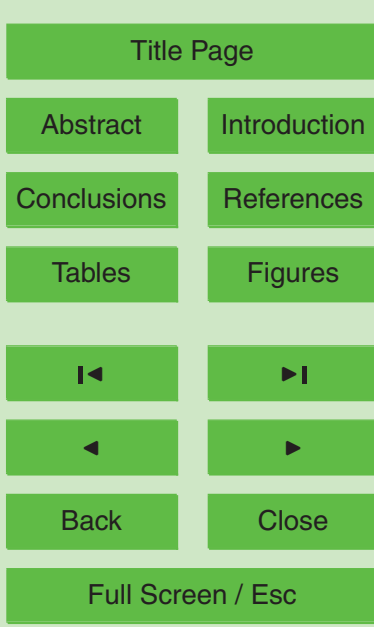

Printer-friendly Version

Interactive Discussion 

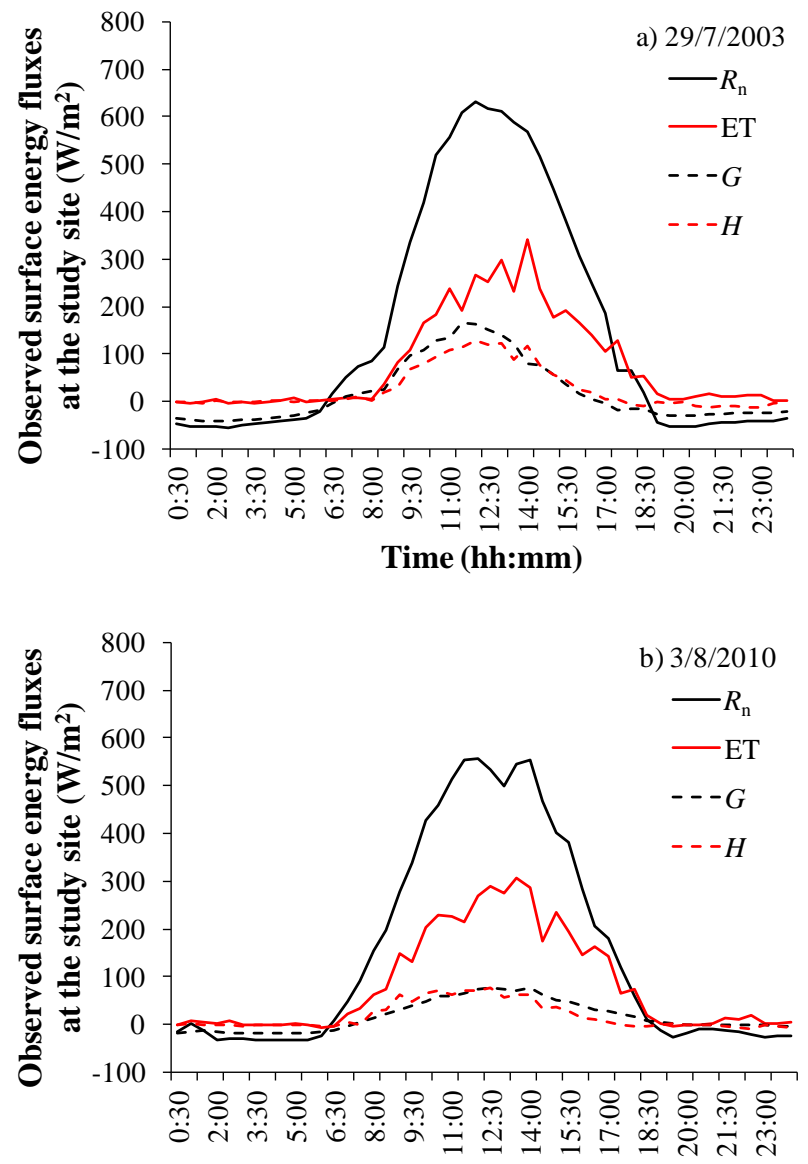

Time (hh:mm)

Fig. 6. Diurnal patterns of observed surface energy fluxes on (a) 29 July 2003 and (b) 3 August 2010 at the study site, including net radiation $\left(R_{\mathrm{n}}\right), \mathrm{ET}$, soil heat flux $(G)$, and sensible heat flux $(H)$.

\section{HESSD}

9, 3029-3062, 2012

\section{Complementary based model for mapping land surface evapotranspiration}

Z. Sun et al.

Title Page

Abstract

Introduction

Conclusions

References

Tables

Figures

14

4

Back

\section{Full Screen / Esc}

Printer-friendly Version

Interactive Discussion 


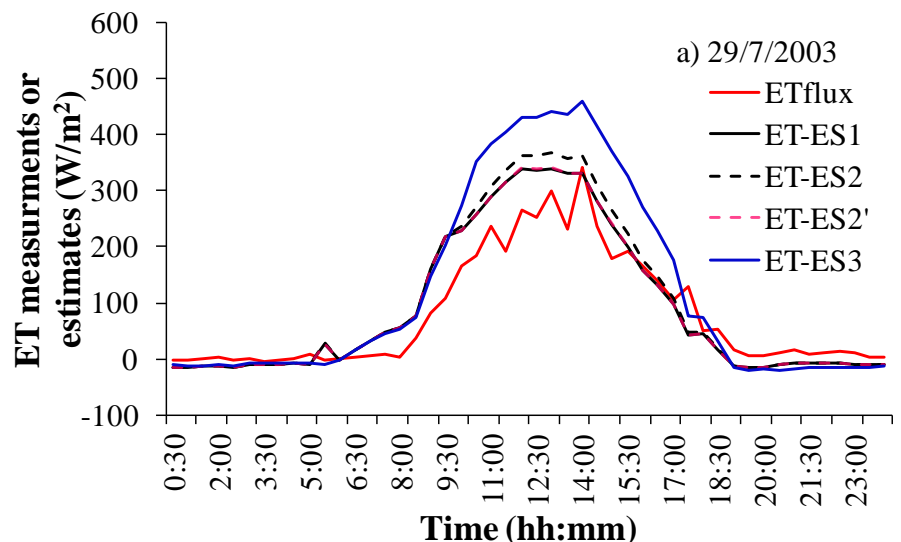

Time (hh:mm)

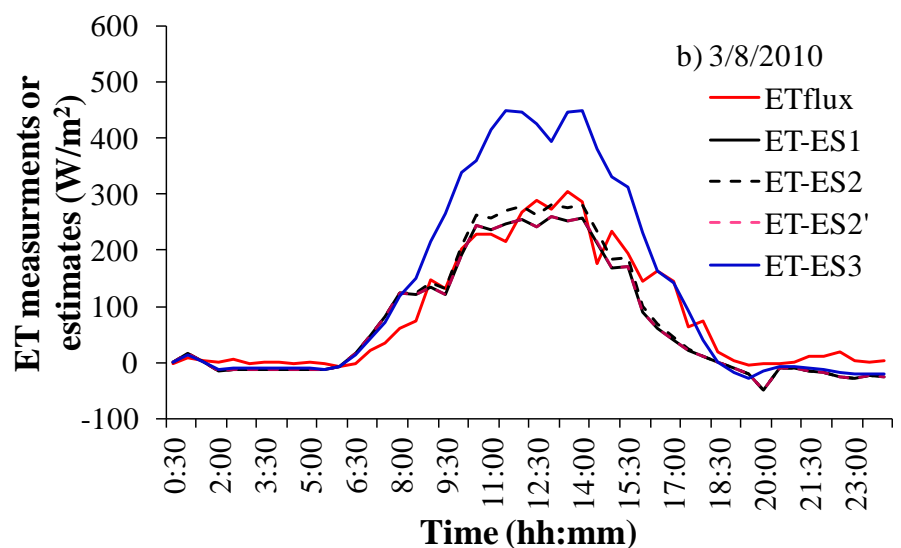

Fig. 7. Diurnal patterns of ET measurements from the flux tower and ET estimates based on four evaluation strategies (ES1, ES2, ES2', and ES3) on (a) 29 July 2003 and (b) 3 August 2010 at the study site.

\section{HESSD}

9, 3029-3062, 2012

\section{Complementary based model for mapping land surface evapotranspiration}

Z. Sun et al.

Title Page

Abstract

Introduction

Conclusions

References

Tables

Figures

14

$\rightarrow$

4

Back

Close

Full Screen / Esc

Printer-friendly Version

Interactive Discussion 

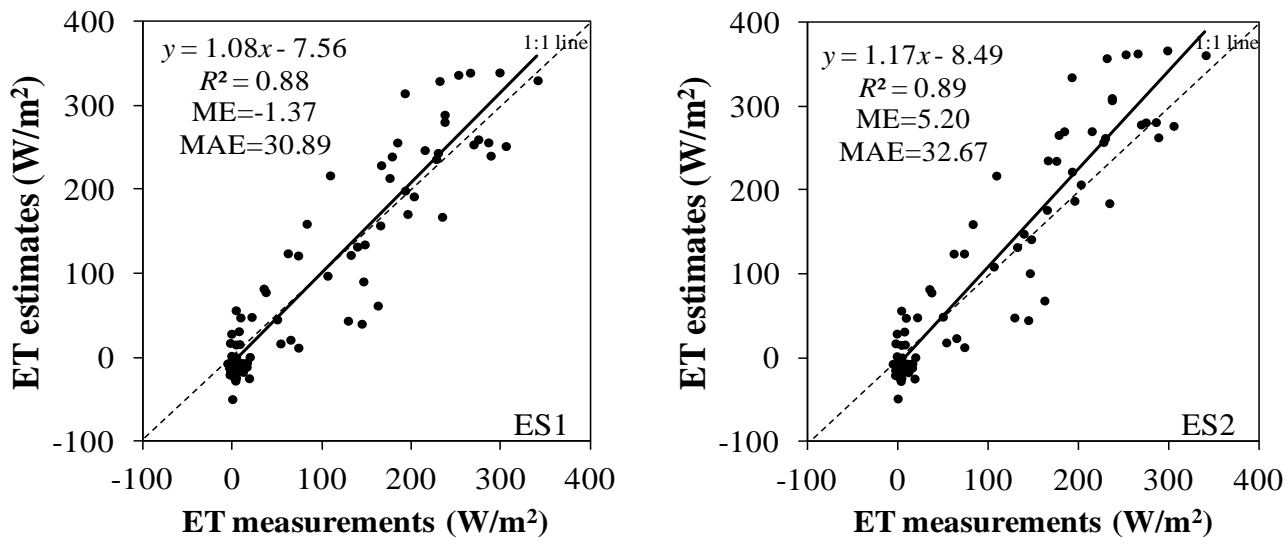

HESSD

9, 3029-3062, 2012

\section{Complementary based model for mapping land surface evapotranspiration}

Z. Sun et al.
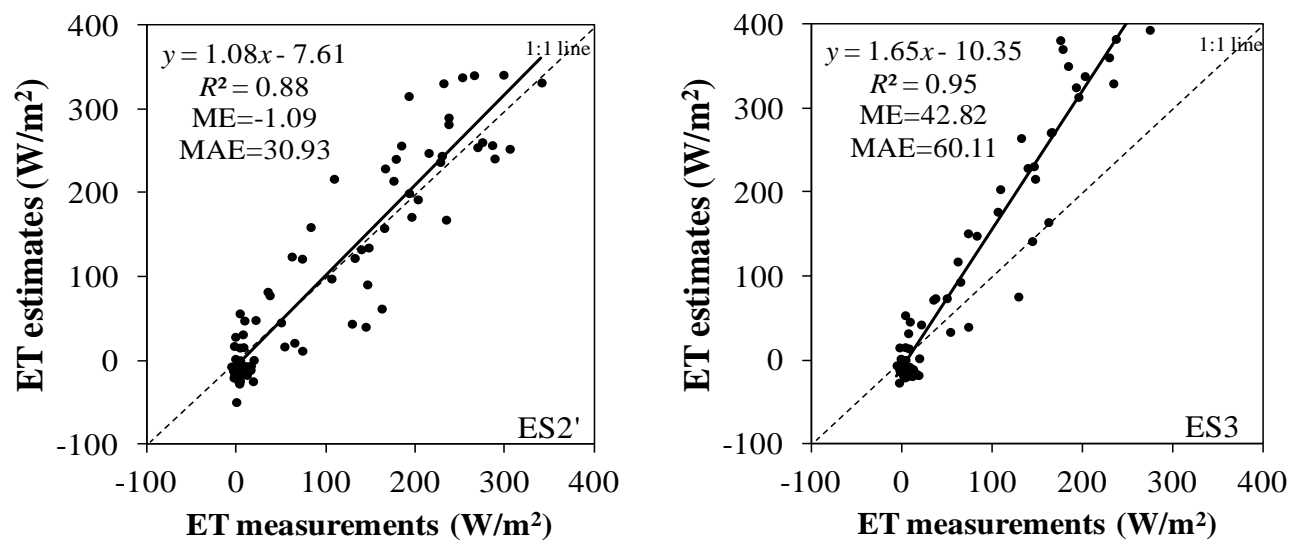

Title Page

Abstract

Conclusions

Tables

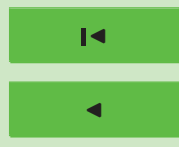

Back

Full Screen / Esc

Printer-friendly Version

Interactive Discussion

ES3) Comparison of ET estimates based on four evaluation strategies (ES1, ES2, ES2, and at the study site. 


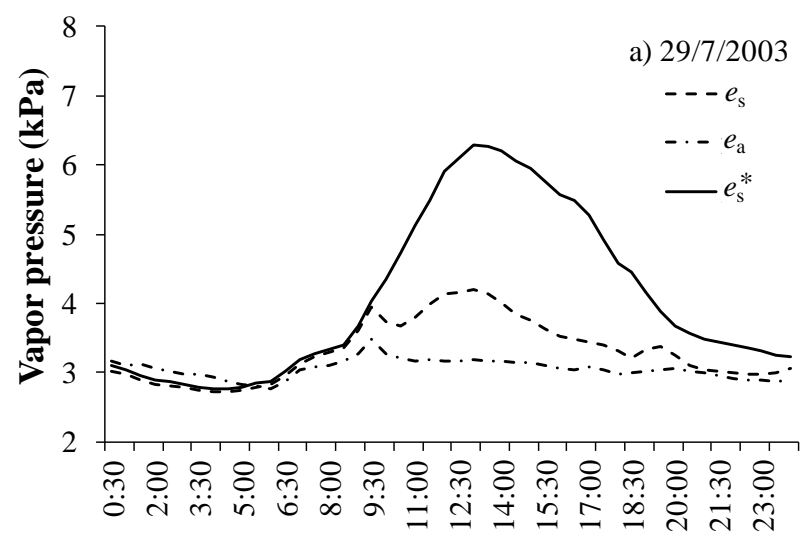

Time (hh:mm)

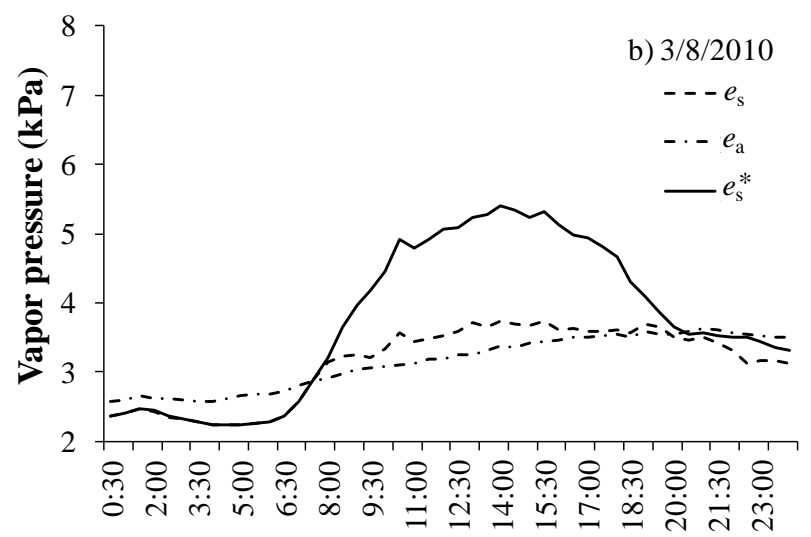

Time (hh:mm)

Fig. 9. Diurnal patterns of surface actual vapor pressure $\left(e_{\mathrm{s}}\right)$, air actual vapor pressure $\left(e_{\mathrm{a}}\right)$, and surface saturated vapor pressure $\left(e_{\mathrm{s}}^{*}\right)$ on (a) 29 July 2003 and (b) 3 August 2010 at the study site.

\section{HESSD}

9, 3029-3062, 2012

\section{Complementary based model for mapping land surface evapotranspiration}

Z. Sun et al.

Title Page

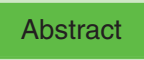

Introduction

Conclusions

References

Tables

Figures

14

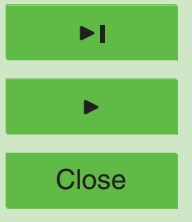

Back

Full Screen / Esc

Printer-friendly Version

Interactive Discussion 


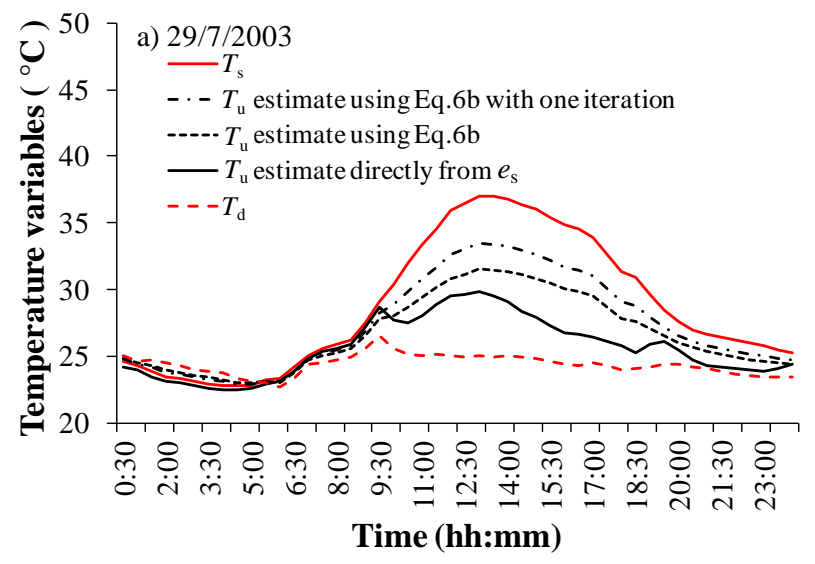

HESSD

9, 3029-3062, 2012

\section{Complementary based model for mapping land surface evapotranspiration}

Z. Sun et al.

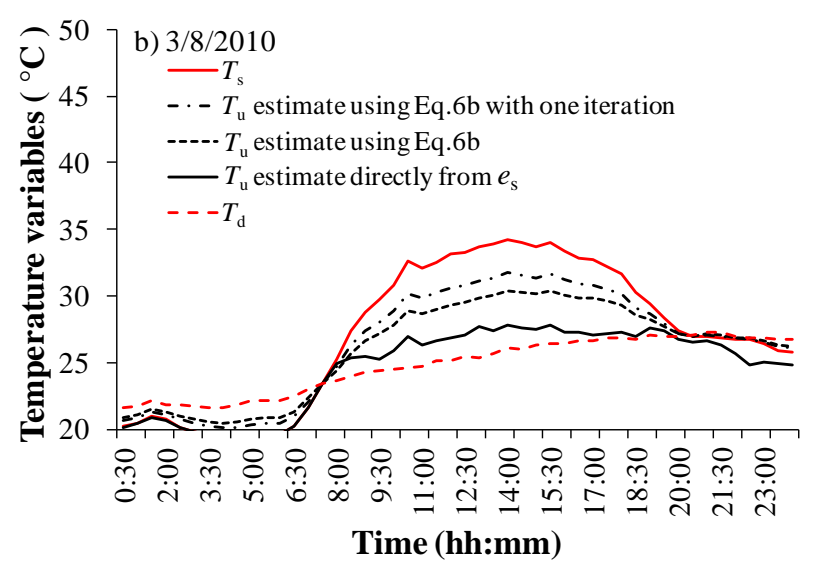

Title Page

\begin{tabular}{|c|c|}
\hline Abstract & Introduction \\
\hline Conclusions & References \\
\hline Tables & Figures \\
\hline I & \\
\hline & \\
\hline Back & Close \\
\hline Full Screen / Esc
\end{tabular}

Fig. 10. Diurnal patterns of measured surface temperature $\left(T_{\mathrm{s}}\right)$, dew point temperature $\left(T_{\mathrm{d}}\right)$ calculated from air actual vapor pressure, $T_{\mathrm{u}}$ estimated directly from surface actual vapor pressure, $T_{\mathrm{u}}$ estimated using Eq. (6b), and $T_{\mathrm{u}}$ estimated using Eq. (6b) with one iteration on (a) 29 July 2003 and (b) 3 August 2010 at the study site. 

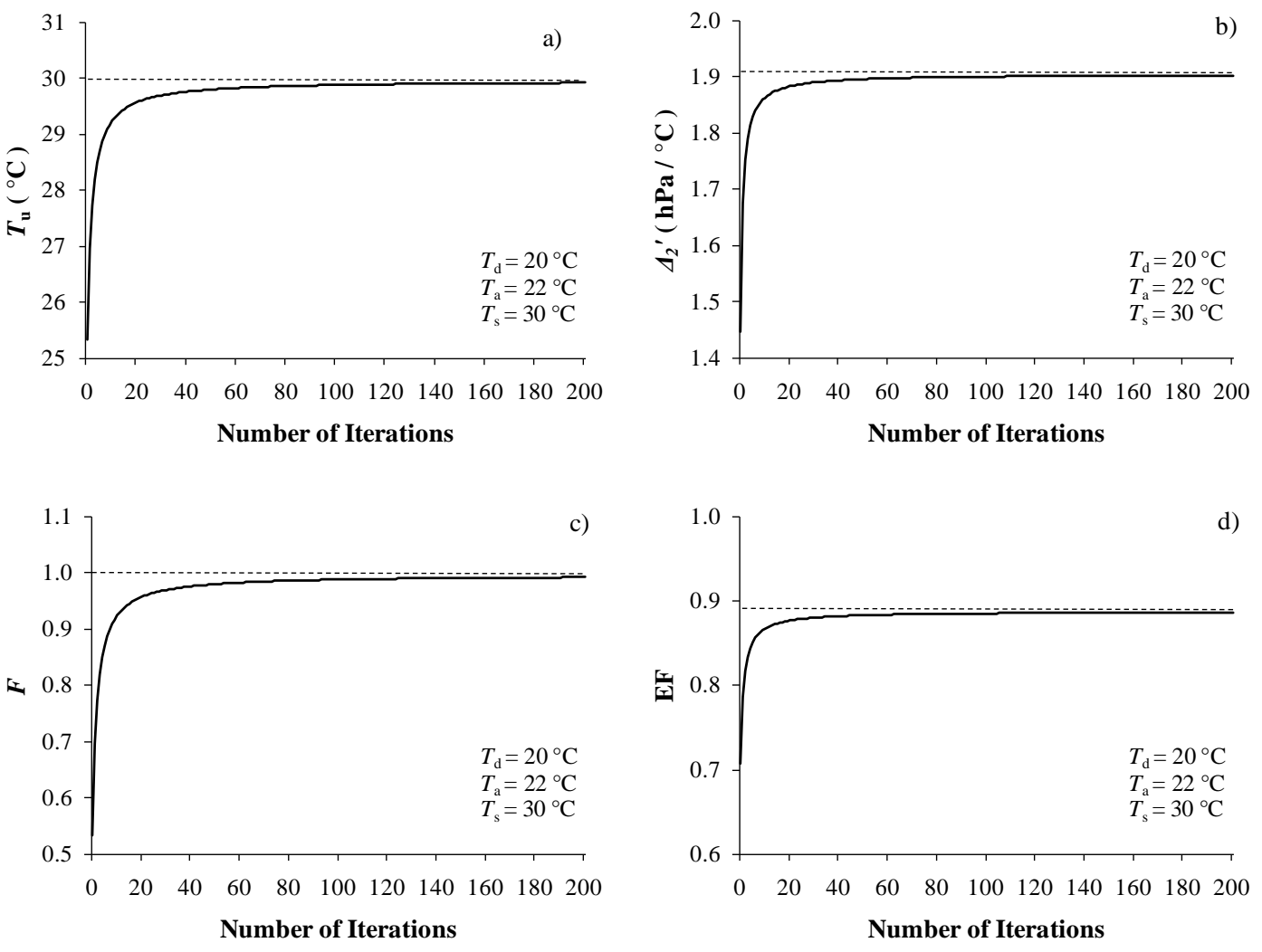

Fig. 11. Simulation results of (a) $T_{\mathrm{u}}$, (b) $\Delta_{2}^{\prime}$, (c) $F$, and (d) EF with the increasing number of iterations using the Venturini method.

\section{HESSD}

9, 3029-3062, 2012

\section{Complementary based model for mapping land surface evapotranspiration}

Z. Sun et al.

Title Page

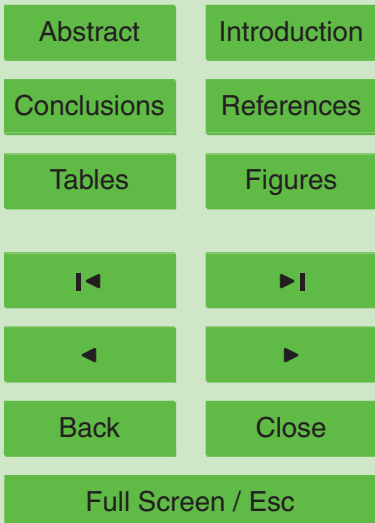

Printer-friendly Version

Interactive Discussion 


\section{HESSD}

\section{9, 3029-3062, 2012}

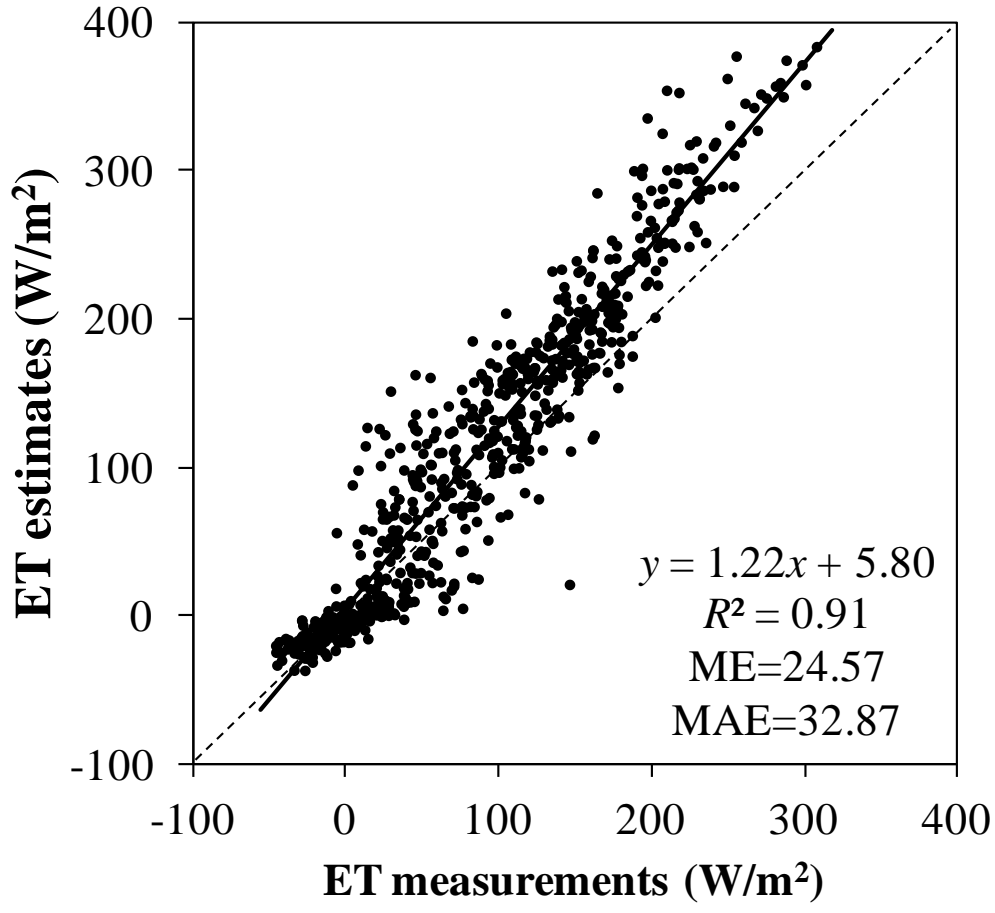

Fig. 12. Comparison of ET measurements from the flux tower against ET estimates from the improved method (Eqs. 1 and 9) proposed in this study.

\section{Complementary based model for mapping land surface evapotranspiration}

Z. Sun et al.

\section{Title Page}

\section{Abstract}

Conclusions

\section{Tables}

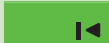

14

4

Back

Full Screen / Esc

Printer-friendly Version 

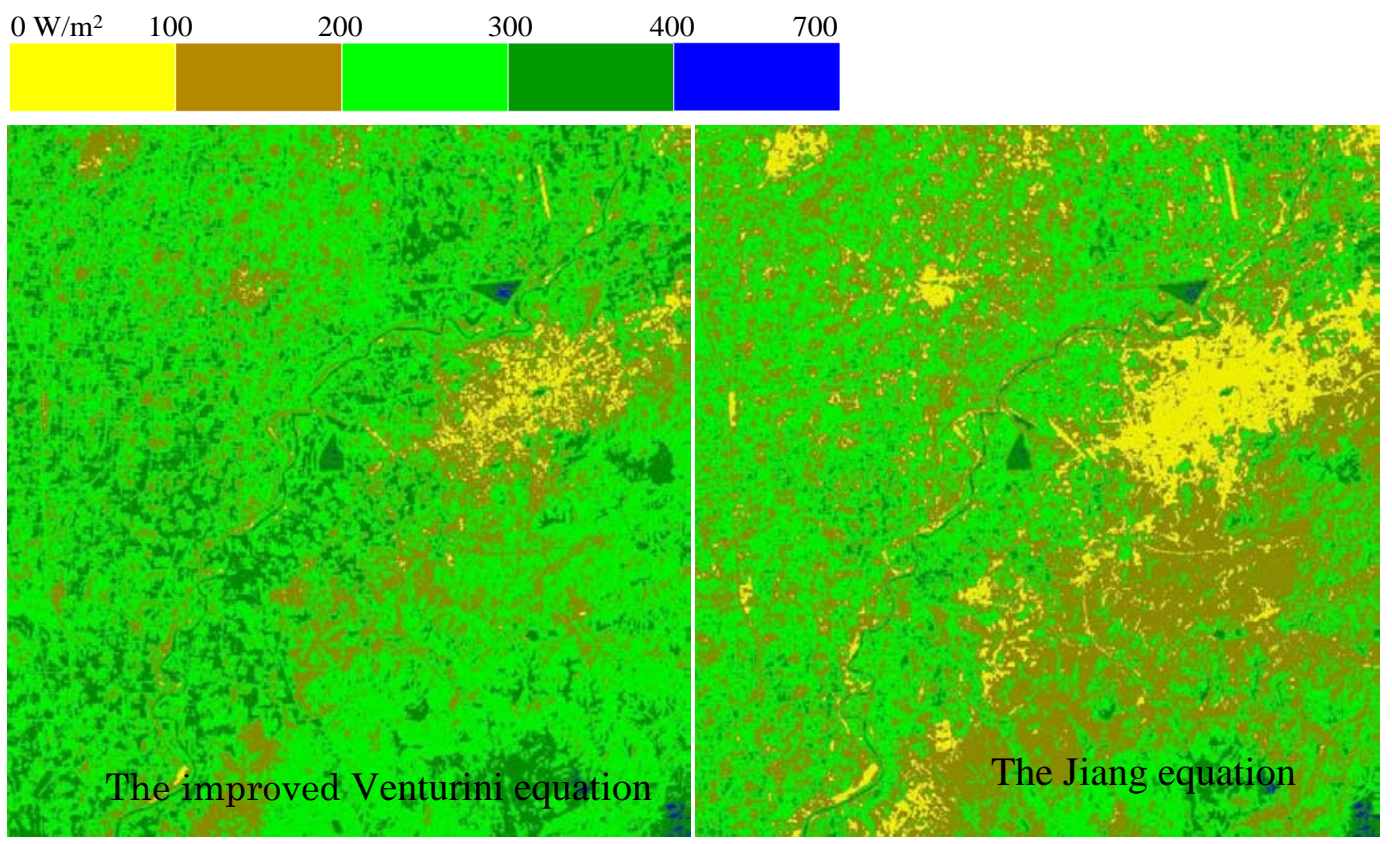

\section{HESSD}

9, 3029-3062, 2012

\section{Complementary based model for mapping land surface evapotranspiration}

Z. Sun et al.

Fig. 13. ASTER-based ET maps on 9 May 2003 using the improved Venturini equation (Eqs. 1 and 9) (left panel) and the Jiang equation (right panel), respectively.

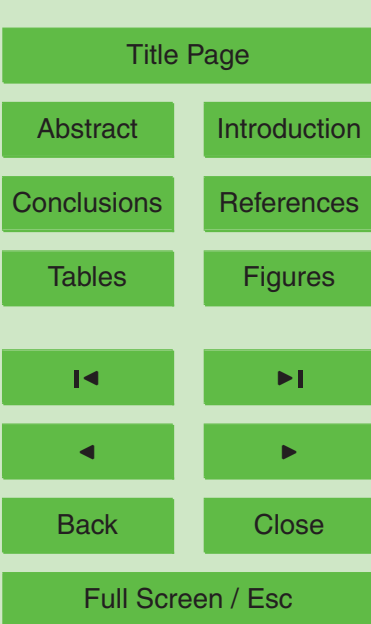

Printer-friendly Version

Interactive Discussion 


\section{HESSD}

9, 3029-3062, 2012

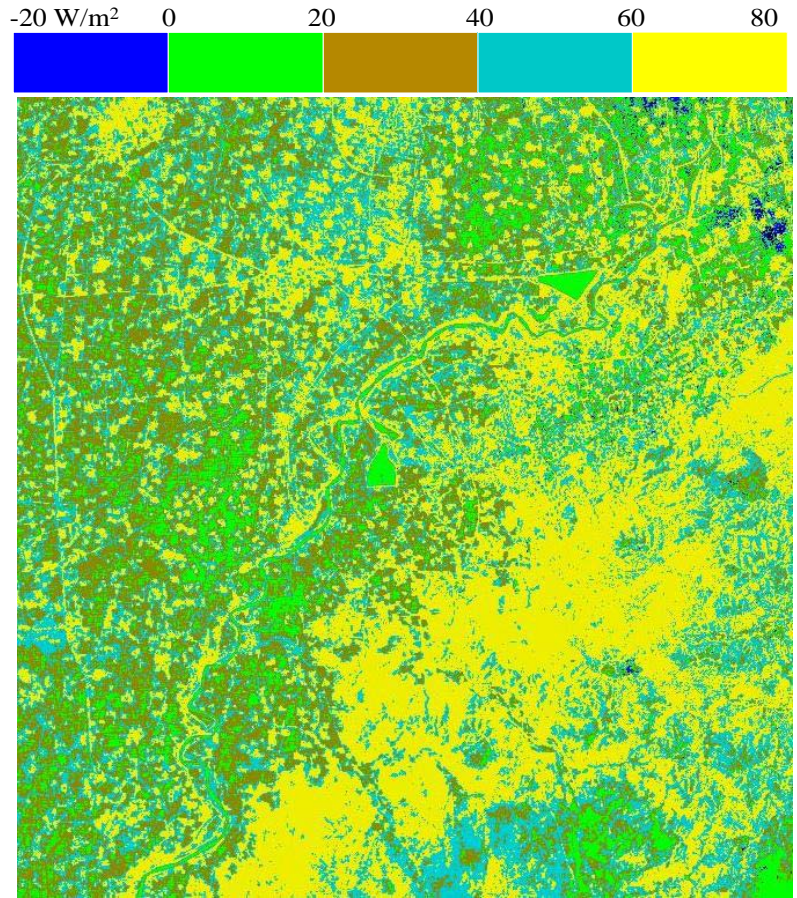

\section{Complementary based model for mapping land surface evapotranspiration}

Z. Sun et al.

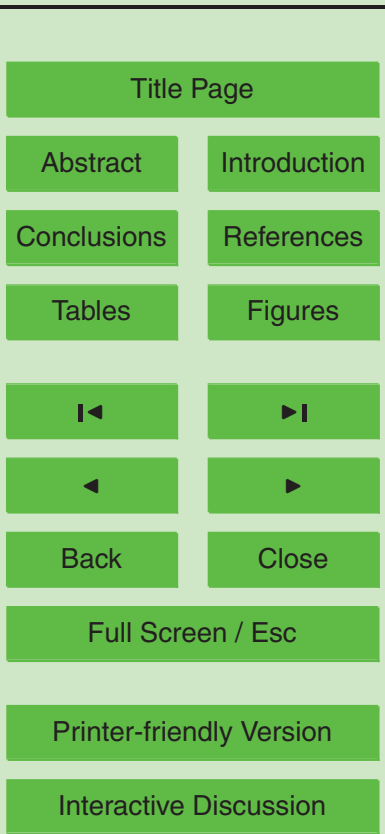

